\title{
Reactive Materials in the Removal of Phosphorus Compounds from Wastewater-A Review
}

\author{
Sylwia Gubernat ${ }^{1,2}$, Adam Masłoń ${ }^{3, * \mathbb{C}}$, Joanna Czarnota ${ }^{3}$ (i) and Piotr Koszelnik ${ }^{3}$ (i) \\ 1 Doctoral School of Engineering and Technical Sciences, Rzeszow University of Technology, \\ Powstańców Warszawy 6, 35-959 Rzeszów, Poland; d512@stud.prz.edu.pl \\ 2 Inżynieria Rzeszów S.A., ul. Podkarpacka 59a, 35-082 Rzeszów, Poland \\ 3 Department of Environmental Engineering and Chemistry, Rzeszow University of Technology, \\ Powstańców Warszawy 6, 35-959 Rzeszów, Poland; askalucz@prz.edu.pl (J.C.); pkoszel@prz.edu.pl (P.K.) \\ * Correspondence: amaslon@prz.edu.pl; Tel.: +48-17-865-1278
}

Received: 23 June 2020; Accepted: 28 July 2020; Published: 30 July 2020

check for updates

\begin{abstract}
Modern technologies designed to treat wastewater containing phosphorus compounds are based on the processes of adsorption and precipitation. In addition, more environmentally friendly and cheaper materials are being sought to ensure greater conformity with overarching assumptions of green chemistry and sustainable development. Against that background, this paper offers a review and analysis of available information on the considered reactive materials that have the capacity to remove phosphorus from wastewater. These materials are categorised as natural (with a sub-division in line with the dominant sorption groups of $\mathrm{Al} / \mathrm{Fe}$ or $\mathrm{Ca} / \mathrm{Mg}$ ), waste, or man-made. Notably, most studies on sorbents have been carried out in laboratory systems via experimentation under static conditions. Among the natural materials, opoka has the highest sorption capacity of $181.20 \mathrm{~g} \mathrm{P} / \mathrm{kg}$, while red mud (in the waste material category) is most efficient at binding phosphorus with a level of $345.02 \mathrm{~g} \mathrm{P} / \mathrm{kg}$. Finally, among the group of commercial materials, Rockfos ${ }^{\circledR}$ has the highest sorption capacity of $256.40 \mathrm{~g} \mathrm{P} / \mathrm{kg}$. In addition, this paper recognises the effect of composition, $\mathrm{pH}$, and physical properties on a reactive material's capacity to absorb phosphorus, as well as the possibility for further potential use in the production of fertilisers.
\end{abstract}

Keywords: reactive materials; adsorption; phosphorus; wastewater treatment

\section{Introduction}

Phosphorus is a major biogenic element and one that is essential in the synthesis of protein molecules; it is also a general ingredient crucial to the ongoing processes in living plant and animal cells. Phosphorus is present in compounds such as adenosine triphosphate (ATP), which transfers energy at the molecular level [1]. From a human perspective, this element is extracted from the ground where inorganic orthophosphate deposits are present. Currently, there are no synthetic substitutes for this element. Among the various biogenic compounds, phosphorus stands out with its sedimentation type cycle, lack of a gaseous phase, and impeded transfer in the environment [2]. Where circumstances are alkaline, phosphorus participates via certain sparingly soluble compounds. Only in an acidic environment does dissolution occur.

Civilisational development and population growth have combined to ensure that phosphorus is increasingly considered a strategic resource. About $82 \%$ of phosphorus obtained is presently used in agriculture, while $7 \%$ is used in the manufacture of animal feed, with the remaining $11 \%$ used in pharmaceuticals and medicine or in the manufacture of detergents [3,4].

Given its status as a key component of agricultural fertilisers, phosphorus is a major agent of the eutrophication process wherein organic matter is generated in excessive amounts as bodies of 
water become over-enriched in nutrients. The consequence is a degradation of natural waters [5]. This explains the desire to remove phosphorus from wastewater to the maximum reasonable (or possible) extent, with recovery of the substance where possible. Large amounts of phosphorus are "lost" to bodies of water, landfills, and wastewater treatment plants [6,7], yet control of the eutrophication process is crucial for ensuring the continuity of aquatic ecosystems in a natural and healthy state. This is vital if people are to be guaranteed drinking water of adequate or desirable quality. To provide adequate protection against eutrophication, wastewater treatment plants have steep requirements for the highest allowable phosphorus concentrations or the minimum percentage of its reduction when discharging treated sewage into water or the ground. In Poland, depending on the Population Equivalent (P.E.: a number expressing the ratio of the sum of the pollution load in wastewater to the individual pollution load in household sewage produced by one person in the same time. In Poland, the BOD5 load from 1 person is assumed to be equal to $60 \mathrm{~g} \mathrm{O} 2$ per $24 \mathrm{~h}$ ), the value of the phosphorus concentration in treated sewage cannot exceed $5 \mathrm{mg} \mathrm{P} / \mathrm{L}$ at PE $<2000,2 \mathrm{mg} \mathrm{P} / \mathrm{L}$ at P.E. in a range of $2000-99,999$, or $1 \mathrm{mg} \mathrm{P} / \mathrm{L}$ at P.E $>100,000$. The minimum percentage of phosphorus reduction is $80 \%$ at P.E. $>10,000[8]$.

At wastewater treatment plants, the main methods for removing $\mathrm{P}$ are based on chemical-precipitation technologies involving lime, aluminium, and iron salts, as well as the Enhanced Biological Phosphorus Removal (EBPR) process [3]. The use of biological methods may, in some cases, prove insufficient to prevent the eutrophication process effectively. In contrast, chemical methods are expensive due to the need for reagents. Modern technologies are based on the adsorption and precipitation processes. However, in accordance with the green chemistry and sustainable development (ecogreen) concepts, cheap and environmentally-friendly materials are currently being sought [3,4].

The basic process for reducing the amount of phosphate ions in an aqueous environment entails moving the processes of phosphorus circulation at the sludge-water phase boundary towards solid-phase deposition by means of chemical precipitation or adsorption [9]. The latter process is one where molecules, atoms, or ions are bound on the surface or interface of the physical phase. Ion adsorption is a complex process dependent on many different factors. Adsorption onto the surface of adsorbents depends on the type used, i.e., the functional groups present on the adsorbent's surface. The process of the "uptake" of ions or molecules through an adsorbent surface can be the result of physical or chemical adsorption, hydrogen bonding, ion-exchange, micro precipitation, or condensation in the adsorbent pores [10-12]. Under certain conditions, the adsorption process continues until achieving a dynamic equilibrium between the adsorbate concentration remaining in the solution and that on the inner surface of the sorbent. The equilibrium adsorption parameters at the solid-liquid border are determined by analysing the process under stationary or dynamic conditions. Static experiments consist of determining the concentrations of the initial solution and a solution in equilibrium with the adsorbent, which is obtained by shaking the solution with the adsorbent material. Column experiments consist of passing the solution through a filtration layer that is a sorbing material. Adsorbate separation between the solution and adsorbent is described by the adsorption isotherm equations, which determine the ratio between the adsorbed substance and the equilibrium concentration of the solution. Equilibrium parameters provide an understanding of the nature and mechanism of adsorption, the types of interactions, and a determination of the process at the molecular level using a theoretical equation or empirical value [10,11].

For phosphorus removal from wastewater, the chemical composition of the adsorbent is important. Reactive materials are those able to remove substances selectively by sorption or precipitation. For phosphorus removal from wastewater or other waters, the potential material should contain compounds able to bind phosphorus, like $\mathrm{Ca}, \mathrm{Mg}, \mathrm{Fe}$, and $\mathrm{Al}$. The mechanism for phosphate adsorption by $\mathrm{Fe}$ and $\mathrm{Al}$ can occur through the exchange of ligands. However for $\mathrm{Ca}$ and $\mathrm{Mg}$, the removal of phosphates is achieved via precipitation of sparingly-soluble tricalcium phosphate or struvite [13]. For this reason, phosphorus-sorbing materials are divided according to the dominant sorption forms: $\mathrm{Al} / \mathrm{Fe}$ or $\mathrm{Ca} / \mathrm{Mg}$. Currently, in technology for wastewater treatment from phosphorus 
compounds, pure reagents containing calcium, iron, and aluminium salts are used in precipitation methods. Due to the tendency to use natural or waste materials, which has both ecological and economic justifications, precipitation methods are commonly replaced by methods based on the filtration, sorption, and biofiltration processes, in which materials such as Leca ${ }^{\circledR}$, Polonite ${ }^{\circledR}$, Rockfos ${ }^{\circledR}$, Pollytag ${ }^{\circledR}$, Filtralite ${ }^{\circledR}$, and Filtra $P$ are used. These materials were created from natural materials subjected to appropriate modifications to obtain a product with high phosphorus removal efficiency [3].

This study discusses the selected reactive materials based on their use in the selective removal of phosphorus from wastewater. After recognizing the largest possible number of tested materials in this area, materials with high phosphorus removal efficiency were selected based on their real use in wastewater treatment technologies or the motivation for further research on the materials (e.g., modifications to improve their properties in this aspect). Other materials were not included in the review due to their poor efficiency in phosphorus binding or lack of economic or technical justification for their use.

The aim of the work was to present and discuss individual reactive materials that were divided into three groups: natural materials and their modifications, waste, synthesized materials and their modifications, and "man-made" materials. Due to differences in the methods for phosphorus binding, natural materials were separated by the dominance of their sorption group ( $\mathrm{Al} / \mathrm{Fe}$ and $\mathrm{Ca} / \mathrm{Mg}$ ). The materials were characterized by determining their sorption capacity and phosphorus removal efficiency (results from tests conducted under static and dynamic conditions were included), and the impact of physicochemical parameters and process conditions on their effectiveness was assessed.

\section{Natural Materials and Their Modifications}

In search of appropriate phosphorus adsorbents, the first research was carried out on natural materials, due to their easy availability, constituted the basis for knowledge to focus research on waste materials in the future, which in turn may translate into a reduction of waste emissions.

\subsection{Materials with a Pronounced Al/Fe Sorption Group}

One of the materials used in this way is bauxite, which was analysed as the main source of aluminium in the form of clay sedimentary rock. For bauxite, Drizo et al. [14] demonstrated an adsorption capacity of $0.61 \mathrm{~g} \mathrm{P} / \mathrm{kg}$, while column tests showed that the material was saturated with $350.00 \mathrm{~g} \mathrm{P} / \mathrm{kg}$ after 70 days. The effect of $\mathrm{pH}$ was investigated, and the maximum adsorption values for phosphates were shown to be achieved under slightly acidic conditions ( $\mathrm{pH}$ 3.2-5.4) (Table 1). Altundogan et al. $[15,16]$ found that the adsorption capacity of thermally activated bauxite (heat-treated at $600{ }^{\circ} \mathrm{C}$ ) was greater for all tested forms of phosphate than for raw bauxite. This likely reflects an increase in the specific surface area (SSA) from $11.0 \mathrm{~m}^{2} / \mathrm{g}$ (raw) to $86.0 \mathrm{~m}^{2} / \mathrm{g}$ (activated as above). For glycerophosphate, thermal modification increased the efficiency of removal from 39.9 to 90.9\% [15,16] (Table 1).

Diatomite was also used in the removal processes for $\mathrm{P}$, with both $\mathrm{pH}$ and material modifications found to have an impact on the sorption capacity reported (Table 2). With natural diatomite, this value is $10.20 \mathrm{~g} \mathrm{P} / \mathrm{kg}$ at $\mathrm{pH}=4.0$. The efficiency of removal is lower at a higher $\mathrm{pH}$ (where $\mathrm{pH}=8.0$, the sorption capacity is of only $1.70 \mathrm{~g} \mathrm{P} / \mathrm{kg}$ ) [17]. A ferrihydrite-modified form of diatomite can be prepared when treatment with $\mathrm{NaOH}$ is followed by the deposition of ferrihydrite on the crude substance. The specific surface area of the material is again increased in this way from 24.77 to $211.10 \mathrm{~m}^{2} / \mathrm{g}$. Such a modification raises the maximum sorption capacity to $37.30 \mathrm{~g} \mathrm{P} / \mathrm{kg}$ at $\mathrm{pH}=4.0$ and $13.60 \mathrm{~g} \mathrm{P} / \mathrm{kg}$ at $\mathrm{pH}=8.5$ [17]. 
Table 1. Sorption properties of various forms of bauxite.

\begin{tabular}{|c|c|c|c|c|c|c|c|c|}
\hline \multirow{2}{*}{$\begin{array}{c}\text { Type of } \\
\text { Phosphate }\end{array}$} & \multicolumn{2}{|c|}{$\begin{array}{c}\text { Bauxite }{ }^{(*)} \text { Mixed with } \\
\text { Distilled Water and Dried } \\
{[15]^{(* *)}}\end{array}$} & \multicolumn{3}{|c|}{ Raw Bauxite ${ }^{(*)}[16]^{(* *)}$} & \multicolumn{3}{|c|}{$\begin{array}{l}\text { Activated Bauxite at } \\
\qquad 600{ }^{\circ} \mathrm{C}[16]^{(* *)}\end{array}$} \\
\hline & $\begin{array}{l}\mathbf{p H} \\
{[-]}\end{array}$ & $\begin{array}{l}\text { Phosphorus } \\
\text { Removal } \\
\text { Efficiency [\%] }\end{array}$ & $\begin{array}{l}\mathrm{pH} \\
{[-]}\end{array}$ & $\begin{array}{l}\text { Phosphorus } \\
\text { Removal } \\
\text { Efficiency [\%] }\end{array}$ & $\begin{array}{l}\text { Sorption } \\
\text { Capacity } \\
{[\mathrm{g} \mathrm{P} / \mathrm{kg}]}\end{array}$ & $\begin{array}{l}\mathrm{pH} \\
{[-]}\end{array}$ & $\begin{array}{l}\text { Phosphorus } \\
\text { Removal } \\
\text { Efficiency [\%] }\end{array}$ & $\begin{array}{l}\text { Sorption } \\
\text { Capacity } \\
\text { [g P/kg] }\end{array}$ \\
\hline Orthophosphate & 4.4 & 67.30 & 4.50 & 67.3 & 0.67 & 4.5 & 97.9 & 0.98 \\
\hline Glycerophosphate & 5.4 & 57.71 & 3.20 & 39.9 & 0.40 & 3.2 & 90.9 & 0.91 \\
\hline Tripolyphosphate & 3.2 & 39.98 & 5.40 & 57.7 & 0.58 & 5.4 & 97.5 & 0.97 \\
\hline
\end{tabular}

${ }^{(*)}$ Material composition: $\mathrm{Fe}_{2} \mathrm{O}_{3}-16.95 \% ; \mathrm{Al}_{2} \mathrm{O}_{3}-56.91 \% ; \mathrm{SiO}_{2}-8.72 \% ; \mathrm{CaO}-0.91 \%$, $\left.{ }^{* *}\right)$ Description of the study: $1 \mathrm{~g}$ material $+100 \mathrm{~mL}$ solution with an initial concentration of $10 \mathrm{mg} \mathrm{P} / \mathrm{L}$; contact time: $2 \mathrm{~h}$; speed: $400 \mathrm{rpm}$; fraction: $<0.074 \mathrm{~mm}$.

Table 2. Studies on the sorption properties of diatomite.

\begin{tabular}{|c|c|c|c|c|}
\hline \multicolumn{2}{|c|}{ Diatomite [17] ${ }^{(*)}$} & \multicolumn{2}{|c|}{$\begin{array}{l}\text { FerrihydriteModified } \\
\text { Diatomite [17] }^{(* *)}\end{array}$} & \multirow{2}{*}{$\begin{array}{c}\text { LanthanumModified } \\
\text { Diatomite [18] }^{(* *)} \\
\begin{array}{c}\text { Phosphorus Removal } \\
\text { Efficiency } \\
{[\%]}\end{array}\end{array}$} \\
\hline $\begin{array}{l}\text { pH } \\
{[-]}\end{array}$ & $\begin{array}{c}\text { Sorption Capacity } \\
\text { According to the } \\
\text { Langmuir Model } \\
{[\mathrm{g} \mathrm{P} / \mathrm{kg}]}\end{array}$ & $\begin{array}{l}\text { pH } \\
{[-]}\end{array}$ & $\begin{array}{c}\text { Sorption Capacity } \\
\text { According to the } \\
\text { Langmuir Model } \\
\text { [g P/kg] }\end{array}$ & \\
\hline $\begin{array}{l}4.0 \\
8.5\end{array}$ & $\begin{array}{c}10.20 \\
1.70\end{array}$ & $\begin{array}{l}4.0 \\
8.5\end{array}$ & $\begin{array}{l}37.30 \\
13.60\end{array}$ & 98.2 \\
\hline
\end{tabular}

(*) Material composition: $\mathrm{Fe}_{2} \mathrm{O}_{3}-1.50 \% ; \mathrm{Al}_{2} \mathrm{O}_{3}-4.00 \% ; \mathrm{MgO}-0.30 \% ; \mathrm{CaO}-0.50 \%$, ${ }^{(* *)}$ Material modification with ferrihydrite at a quantity of $0.24 \mathrm{~g} \mathrm{Fe} / \mathrm{g}$. Description of the study: $100 \mathrm{~mL}$ solutions with initial concentrations of 0-40 mg P/L + $0.05 \mathrm{~g}$ material, shaken at $200 \mathrm{rpm}$ for $72 \mathrm{~h},{ }^{(* *)}$ Description of the study: $0.08 \mathrm{~g}$ material + solution with an initial concentration of $5 \mathrm{mg} / \mathrm{L}$.

The research conducted by Xie et al. [18] likewise documented an increased SSA of diatomite following modification with lanthanum from 0.64 to $52.60 \mathrm{~m}^{2} / \mathrm{g}$. In these circumstances, the removal effectiveness from a solution of $5 \mathrm{mg} \mathrm{P} / \mathrm{L}$ reached $98.2 \%$ at the outset.

Another material studied for its capacity to remove phosphorus compounds in wastewater treatment is akadama clay. Research carried out with this sorbent $1 \mathrm{~g}$ of material $+200 \mathrm{~mL}$ of solution with an initial concentration of $20 \mathrm{mg} \mathrm{P} / \mathrm{L}$, was shaken at a speed of $100 \mathrm{rpm}$ for 0 to $540 \mathrm{~min}$ ) showed that the natural form of akadama clay has a maximum phosphorus adsorption capacity of $5.88 \mathrm{~g}$ $\mathrm{P} / \mathrm{kg}$ [19]. However, the efficiency increased further to $9.19 \mathrm{~g} \mathrm{P} / \mathrm{kg}$ under $\mathrm{H}_{2} \mathrm{SO}_{4}$ activation. Furthermore, this treated form of akadama clay differs from the natural form in providing more effective removal over a wider $\mathrm{pH}$ range (from 3.0 to 6.0). In this case, the presence of competitor anions, especially citrate and carbonate, were shown to negatively impact phosphate adsorption. Table 3 compares the results for natural and modified akadama clay.

Table 3. Comparison of the properties of natural and modified akadama clay.

\begin{tabular}{cccccc}
\hline References & Material & $\begin{array}{c}\text { Specific } \\
\text { Surface Area } \\
{\left[\mathbf{m}^{2} / \mathbf{g}\right]}\end{array}$ & $\begin{array}{c}\text { Sorption Capacity } \\
\text { According to the } \\
\text { Kinetic Model [g } \\
\mathbf{P} / \mathbf{k g}]\end{array}$ & $\begin{array}{c}\text { Maximum Sorption } \\
\text { Capacity According } \\
\text { to the Langmuir Model [g } \\
\mathbf{P} / \mathbf{k g}]\end{array}$ \\
\hline \multirow{2}{*}[19]{} & $\begin{array}{c}\text { akadama } \\
\text { clay }\end{array}$ & $\begin{array}{c}\text { activated } \mathrm{H}_{2} \mathrm{SO}_{4} \\
\text { natural }\end{array}$ & 75.27 & 3.95 & 9.19 \\
& 117.67 & 3.41 & 5.88 \\
\hline
\end{tabular}

Laterite represents yet another alternative phosphorus-sorbing material, whose characteristics are shown in Table 4. Under the Langmuir model, the maximum sorption capacity in this case is $2.73 \mathrm{~g}$ $\mathrm{P} / \mathrm{kg}$. However, $1.65 \mathrm{~g} \mathrm{P} / \mathrm{kg}$ proved possible, even when the concentration of phosphorus compounds was very low at $0.035 \mathrm{mg} P / \mathrm{L}$, demonstrating that this material could have applications in wastewater treatment [20]. Laterite's effectiveness at removing $P$ is also greater at higher temperatures [21], and an increase is likewise obtained if laterite is modified by acidification [19]. 
Table 4. Sorption properties of laterite in natural or modified versions.

\begin{tabular}{|c|c|c|c|c|c|}
\hline \multicolumn{2}{|c|}{ Laterite $[22]^{(*)}$} & \multicolumn{2}{|c|}{$\begin{array}{c}\text { Acidified Laterite, ByProduct of } \\
\text { the Production of Ferric } \\
\text { Aluminium Sulphate [20] }{ }^{(* *)}\end{array}$} & \multicolumn{2}{|c|}{ Laterite $[21]^{(* *)}$} \\
\hline $\begin{array}{c}\text { Initial } \\
\text { Phosphorus } \\
\text { Concentration } \\
{[\mathrm{mg} \mathrm{P} / \mathrm{L}]}\end{array}$ & $\begin{array}{c}\text { Phosphorus } \\
\text { Removal } \\
\text { Efficiency } \\
{[\%]}\end{array}$ & $\begin{array}{c}\text { Initial } \\
\text { Phosphorus } \\
\text { Concentration } \\
{[\mathrm{mg} \mathrm{P} / \mathrm{L}]}\end{array}$ & $\begin{array}{l}\text { Sorption } \\
\text { Capacity } \\
{[\mathrm{g} \mathrm{P} / \mathrm{kg}]}\end{array}$ & $\begin{array}{c}\text { Temperature } \\
{\left[{ }^{\circ} \mathrm{C}\right]}\end{array}$ & $\begin{array}{l}\text { Sorption } \\
\text { Capacity } \\
{[\mathrm{g} \mathrm{P} / \mathrm{kg}]}\end{array}$ \\
\hline 50 & 60.0 & 0.035 & 1.65 & 24.85 & $1.07^{(\mathrm{L})}$ \\
\hline 5-10 & $80.0-90.0$ & $5-50$ & $2.73^{(\mathrm{L})}$ & 34.85 & $1.14^{(\mathrm{L})}$ \\
\hline \multicolumn{6}{|c|}{$\begin{array}{l}\left.{ }^{*}\right) \text { Material composition: } \mathrm{Fe}_{2} \mathrm{O}_{3}-26.70 \% ; \mathrm{Al}_{2} \mathrm{O}_{3}-39.80 \% \text {; description of the study: } 10 \mathrm{~g} \text { material (fraction } 2.0-3.4 \mathrm{~mm} \text { ) } \\
+100 \mathrm{~mL} \text { solution, shaken at } 65 \mathrm{rpm},{ }^{(* *)} \mathrm{Description}^{*} \text { of the study: material } 1 \mathrm{~g} / \mathrm{L}+50 \mathrm{~mL} \text { solution, shaken for } 24 \mathrm{~h} \text { at } \\
100 \mathrm{rpm},{ }^{(* *)} \text { Material composition: } \mathrm{Fe}_{2} \mathrm{O}_{3}-14.20 \% \text {; } \mathrm{Al}_{2} \mathrm{O}_{3}-24.40 \% ; \mathrm{MgO}-0.73 \% \text {; CaO- } 0.74 \% \text {; description of } \\
\text { the study: } 50 \mathrm{~mL} \text { solutions with initial concentrations of } 5-30 \mathrm{mg} \mathrm{P} / \mathrm{L}+0.3 \mathrm{~g} \text { material, shaken for } 12 \mathrm{~h} \text { at } 170 \mathrm{rpm} \\
\text { (L) Sorption capacity according to the Langmuir model. }\end{array}$} \\
\hline
\end{tabular}

Shale has also been applied to the removal of phosphorus from wastewater in static experiments by Drizo et al. [14], which obtained a maximum sorption capacity equal to $0.65 \mathrm{~g} \mathrm{P} / \mathrm{kg}$ (compared to $0.75 \mathrm{~g} \mathrm{P} / \mathrm{kg}$ in column tests). Table 5 details these sorption properties.

Table 5. Sorption properties of shales.

\begin{tabular}{|c|c|c|c|c|c|c|c|}
\hline References & Material & $\begin{array}{c}\text { Porosity } \\
{[\%]}\end{array}$ & $\begin{array}{c}\text { Type of } \\
\text { Experiment }\end{array}$ & $\begin{array}{c}\text { Hydraulic } \\
\text { Conductivity } \\
{[\mathrm{m} / \mathrm{s}]}\end{array}$ & $\begin{array}{c}\text { Fraction } \\
\text { [mm] }\end{array}$ & $\begin{array}{c}\text { Initial } \\
\text { Phosphorus } \\
\text { Concentration } \\
{[\mathrm{mg} \mathrm{P} / \mathrm{L}]}\end{array}$ & $\begin{array}{l}\text { Sorption } \\
\text { Capacity } \\
\text { [g P/kg] }\end{array}$ \\
\hline \multirow{3}{*}{ [14] } & \multirow{3}{*}{ Shale } & \multirow{3}{*}{38} & \multirow{3}{*}{$\begin{array}{l}\text { column } \\
\text { static }^{(*)}\end{array}$} & 0.001 & $6.8-12.6^{(* *)}$ & 45 & 0.40 \\
\hline & & & & 0.001 & $6.8-12.6^{(* *)}$ & 100 & 0.75 \\
\hline & & & & 0.001 & $6.8-12.6^{(* *)}$ & $2.5-40$ & $0.65^{(\mathrm{L})}$ \\
\hline \multirow{4}{*}[23,24]{} & \multirow{4}{*}{ Shale } & \multirow{4}{*}{70} & \multirow[b]{2}{*}{ static $^{(* * *)}$} & 0.0009 & 2.0 & $0-1000$ & $0.17 \pm 0.01$ \\
\hline & & & & 0.0076 & $2.0-4.7$ & $0-1000$ & $0.14 \pm 0.01$ \\
\hline & & & \multirow{2}{*}{ static $^{(* * * *)}$} & 0.0009 & 2.0 & $0-100$ & $0.50 \pm 0.04$ \\
\hline & & & & 0.0076 & $2.0-4.7$ & $0-100$ & $0.25 \pm 0.04$ \\
\hline \multirow{4}{*}{ [25] } & \multirow{4}{*}{ Shale } & \multirow{4}{*}{50} & \multirow{3}{*}{$\operatorname{static}^{(* * * *)}$} & \multirow{3}{*}{0.032} & \multirow{3}{*}{$<0.4$} & $5-250$ & $0.51^{(\mathrm{L})}$ \\
\hline & & & & & & 5 & 0.06 \\
\hline & & & & & & 25 & 0.023 \\
\hline & & & column & 0.032 & $1.0-2.0$ & 25 & 0.17 \\
\hline
\end{tabular}

${ }^{(*)}$ Description of the study: solution $+20 \mathrm{~g}$ material, shaken at $60 \mathrm{rpm}$ for $24 \mathrm{~h},{ }^{(*)}$ Fraction $6.8-12.6 \mathrm{~mm}: 41.9 \%$ of all material, ${ }^{(* *)}$ Description of the study: solution $+3 \mathrm{~g}$ material, shaken for $24 \mathrm{~h}$, centrifuged at $5000 \mathrm{rpm}$, ${ }^{(* * *)}$ Description of the study: solution $+1 \mathrm{~g}$ material, shaken for $24 \mathrm{~h}$, centrifuged at $5000 \mathrm{rpm},{ }^{(* * * * *)}$ Description of the study: solution + dose of material $0.08 \mathrm{~g} / \mathrm{L}$, shaken at $300 \mathrm{rpm}$ for $24 \mathrm{~h}$, (L) Sorption capacity according to the Langmuir model.

Moreover, Cyrus et al. [23,24] achieved a maximum sorption capacity of $0.17 \mathrm{~g} \mathrm{P} / \mathrm{kg}$, where the initial concentration was $1000 \mathrm{mg} P / \mathrm{L}$ compared to $0.50 \mathrm{~g} \mathrm{P} / \mathrm{kg}$, with an initial concentration only one-tenth as high. Sorption experiments generally reveal lower percentage sorption capacity where $\mathrm{P}$ concentrations in solution are progressively higher. Shales of a larger fraction size also offer poorer efficiency in removing phosphorus due to their lower surface area and higher hydraulic conductivity than smaller material particles [23,24]. Likewise, recent column studies confirmed the maximum sorption capacities for material of 0.06 and $0.23 \mathrm{~g} \mathrm{P} / \mathrm{kg}$, where the initial $\mathrm{mg} \mathrm{P} / \mathrm{L}$ concentrations were 5 and 25, respectively [25]. Further, the amount of porosity (the ratio of the volume of voids inside the material to the volume of the whole body) did not affect the sorption capacity of shale. Nevertheless, sorption materials must have a porous structure adequate for their physicochemical properties. The porosity of the material will determine the degree of the removal of impurities of various sizes and thus allow the sorption process to occur [10].

In the discussed aspect of wastewater treatment from phosphorus compounds, the next proposed sorbent is zeolite. Phosphate sorption by the natural form of this material (the main component 
is clinoptilolite), proceeds through various mechanisms: ion exchange, physical sorption and chemisorption. The relevant literature (as summarised in Table 6) shows the sorption capacities for this substance to range from $0.46 \mathrm{~g} \mathrm{P} / \mathrm{kg}$ [14] to $2.15 \mathrm{~g} \mathrm{P} / \mathrm{kg}$ [26]. Other work obtained $67.5 \%$ phosphorus removal using zeolite, where the contact time was $180 \mathrm{~min}$ [27]. Zeolite synthesised from fly ash (ZFA) has also been the subject of analysis, as have versions modified with $\mathrm{Ca}^{2+}$ (ZFA-Ca), $\mathrm{Fe}^{3+}$ (ZFA-Fe), or $\mathrm{Al}^{3+}$ (ZFA-Al) [13]. Experiments run with initial concentrations of $1000 \mathrm{mg} \mathrm{P} / \mathrm{L}$ revealed a universally high efficiency of removal with zeolite, as Table 6 illustrates. However, where $P$ is present at the low concentrations characteristic of real wastewater, ZFA-Al and ZFA-Fe work best.

Table 6. Sorption properties of zeolite, or modified versions of it.

\begin{tabular}{|c|c|c|c|}
\hline References & Description of the Study & Material & $\begin{array}{c}\text { Maximum Sorption } \\
\text { Capacity According to } \\
\text { the Langmuir Model } \\
{[\mathrm{g} \mathrm{P} / \mathrm{kg}]}\end{array}$ \\
\hline [14] & $\begin{array}{l}\text { solutions with initial concentrations of } \\
2.5-40 \mathrm{mg} \mathrm{P} / \mathrm{L}+20 \mathrm{~g} \text { material (fraction: } \\
6.8-12.6 \mathrm{~mm} \text { ), shaken at } 60 \mathrm{rpm} \text { for } 24 \mathrm{~h}\end{array}$ & zeolite & 0.46 \\
\hline [27] & $\begin{array}{l}\text { solutions with initial concentrations of } \\
500-10,000 \mathrm{mg} \mathrm{P} / 1+3 \mathrm{~g} \text { material, } \\
\text { shaken for } 48 \mathrm{~h} \text { at } 100 \mathrm{rpm} \text {, centrifuged } \\
\text { at } 5000 \mathrm{rpm} \text { for } 10 \mathrm{~min}\end{array}$ & zeolite & 2.15 \\
\hline \multirow{2}{*}{ [13] } & $\begin{array}{c}\text { solutions with initial concentrations of } \\
0.5-1000 \mathrm{mg} \mathrm{P} / \mathrm{L}+0.4 \mathrm{~g} \text { material, } \\
\text { shaken for } 24 \mathrm{~h}\end{array}$ & $\begin{array}{l}\text { zeolite synthesized from } \\
\text { fly ash ZFA }{ }^{(*)} \\
\text { zeolite }^{(* *)}\end{array}$ & $\begin{array}{c}35.31 \\
2.19\end{array}$ \\
\hline & $\begin{array}{c}0.4 \mathrm{~g} \text { material + solution with an initial } \\
\text { concentration of } 1000 \mathrm{mg} \mathrm{P} / \mathrm{L} \text {, shaken } \\
\text { for } 24 \mathrm{~h}\end{array}$ & $\begin{array}{l}\text { ZFA-Ca } \\
\text { ZFA-Fe } \\
\text { ZFA-Al } \\
\text { ZFA-Mg }\end{array}$ & $\begin{array}{l}54.17 \\
31.75 \\
30.46 \\
32.79\end{array}$ \\
\hline
\end{tabular}

${ }^{(*)}$ Material composition: $\mathrm{Fe}_{2} \mathrm{O}_{3}-9.00 \% ; \mathrm{Al}_{2} \mathrm{O}_{3}-18.90 \% ; \mathrm{SiO}_{2}-34.40 \% ; \mathrm{MgO}-1.00 \% ; \mathrm{CaO}-7.30 \%$, ${ }^{(* *)}$ Material composition: $\mathrm{Fe}_{2} \mathrm{O}_{3}-0.20 \% ; \mathrm{Al}_{2} \mathrm{O}_{3}-11.00 \% ; \mathrm{SiO}_{2}-69.50 \% ; \mathrm{MgO}-0.10 \% ; \mathrm{CaO}-2.60 \%$.

Bentonite is another reactive material in which the $\mathrm{Al} / \mathrm{Fe}$ sorption group prevails. Bentonite's properties make it suitable for modifications to increase natural sorption capacity. As Table 7 shows, these modifications are able to considerably increase the material's SSA beyond the $37.10 \mathrm{~m}^{2} / \mathrm{g}$ that characterises the natural substance. Among all the bentonite modifications, the best adsorbent is the lanthanum (III)-modified version, which attains a maximum adsorption capacity of $14.00 \mathrm{~g} \mathrm{P} / \mathrm{kg}$. The similar value of $12.70 \mathrm{~g} \mathrm{P} / \mathrm{kg}$ obtained for hydroxyAl-modified bentonite demonstrates that bentonite-based adsorbents can be highly efficient in removing $\mathrm{P}[28,29]$.

Table 7. Comparison of sorption properties among variously modified types of bentonite.

\begin{tabular}{cccc}
\hline References & Material & $\begin{array}{c}\text { Specific Surface Area } \\
{\left[\mathbf{m}^{2} / \mathbf{g}\right]}\end{array}$ & $\begin{array}{c}\text { Maximum Sorption } \\
\text { Capacity According to } \\
\text { the Langmuir Model } \\
{[\mathrm{g} \mathrm{P} / \mathbf{k g}]}\end{array}$ \\
\hline \multirow{2}{*}[29]{} & hydroxyAl-modified bentonite & 200.00 & 12.70 \\
& hydroxyFe-modified bentonite & 143.00 & 11.20 \\
{$[28]$} & hydroxyAl-Fe-modified bentonite & 94.90 & 10.50 \\
& lanthanum(III)-modified bentonite & 115.00 & 14.00 \\
\hline
\end{tabular}

\subsection{Materials with a Pronounced $\mathrm{Ca} / \mathrm{Mg}$ Sorption Group}

Calcite is a natural material whose composition is dominated by the $\mathrm{Ca} / \mathrm{Mg}$ sorption group. Research on industrial wastewater containing phosphorus in the form of orthophosphates, which are produce during the production of thin-film-transistor liquid-crystal display (TFT-LCD) screens has yielded a maximum sorption capacity for calcite equal to $13.26 \mathrm{~g} \mathrm{P} / \mathrm{kg}$, with a $\mathrm{pH}$ of 6.5 [30]. Other work 
likewise confirmed a marked capacity to absorb phosphorus [31,32], especially when the environment is alkaline ( $\mathrm{pH} 7.6-12.0)$ and where phosphate/adsorbent ratios are high. Moreover, calcite can be regarded as environmentally friendly, given its lack of need for further processing and thus its potential use in conditioning acidic soils [31].

Dolomite has also been used to remove $\mathrm{P}$ from wastewater, with a demonstrated sorption capacity of $51.02 \mathrm{~g} \mathrm{P} / \mathrm{kg}$, where $60 \mathrm{mg} \mathrm{P} / \mathrm{L}$ is the initial concentration [33]. Experiments using distilled water (initial $0.28 \mathrm{mg} \mathrm{P} / \mathrm{L})$, ground water $(0.34 \mathrm{mg} / \mathrm{L})$, tap water $(0.34 \mathrm{mg} \mathrm{P} / \mathrm{L})$, and wastewater $(0.56 \mathrm{mg} \mathrm{P} / \mathrm{L})$ found respective sorption capacities for dolomite of $0.06,0.072,0.05$, and $0.05 \mathrm{~g} \mathrm{P} / \mathrm{kg}$. The maximum sorption capacities determined via the Freundlich and Langmuir models are 0.12 and $0.093 \mathrm{~g} \mathrm{P} / \mathrm{kg}$, respectively [34]. Table 8 offers a further characterisation of dolomite. Research into the effects of additional factors in the adsorption of phosphorus by dolomite found that slightly more $\mathrm{P}$ is removed where the $\mathrm{pH}$ and/or temperature are higher. Changes to the structure and pore-size distribution may occur with calcination [35].

Table 8. Sorption properties of dolomite.

\begin{tabular}{|c|c|c|c|c|}
\hline References & Description of the Study & Type of Medium & $\begin{array}{c}\text { Initial Phosphorus } \\
\text { Concentration } \\
{[\mathrm{mg} \mathrm{P} / \mathrm{L}]}\end{array}$ & $\begin{array}{l}\text { Sorption Capacity } \\
{[\mathrm{g} \mathrm{P} / \mathrm{kg}]}\end{array}$ \\
\hline \multirow{4}{*}[34]{} & \multirow{3}{*}{$\begin{array}{l}\text { column: material }<0.074 \mathrm{~mm} \text {, } \\
\text { flow rate } 1 \mathrm{~mL} / \mathrm{min}\end{array}$} & distilled water & 0.28 & 0.06 \\
\hline & & ground water & 0.34 & 0.07 \\
\hline & & tap water & 0.34 & 0.05 \\
\hline & $\begin{array}{c}\text { static: solution }+5-40 \mathrm{~g} \text { material, } \\
\text { shaken at } 200 \mathrm{rpm}\end{array}$ & synthetic solution & 9.60 & 0.93 \\
\hline \multirow[t]{2}{*}[33]{} & $\begin{array}{l}\text { static: } 0.2 \text { g material }+100 \mathrm{~mL} \\
\text { solution, shaken at } 90 \mathrm{rpm},\end{array}$ & synthetic solution & $10.00-60.00$ & $9.74-52.91^{(*)}$ \\
\hline & centrifuged at $3750 \mathrm{rpm}$ & & $10.00-60.00$ & $7.34-51.02^{(* *)}$ \\
\hline
\end{tabular}

${ }^{(*)}$ Temperature of conducting the experiment: $20^{\circ} \mathrm{C},{ }^{(*)}$ Temperature of conducting the experiment: $40{ }^{\circ} \mathrm{C}$.

Yin et al. [36] used naturally occurring sepiolite, which is rich in calcium ( $\mathrm{CaO}$ at 22.3\%). Experimentation showed that the phosphorus sorption across 5-1000 mg P/L concentrations can be accurately described by the Freundlich equation. The estimated maximum sorption capacity was $32.00 \mathrm{~g} \mathrm{P} / \mathrm{kg}$, which is rare for a natural material. However, phosphate adsorption is progressively lower when the $\mathrm{pH}$ value increases to 6.0 from 3.0 and experiences a sharp decline under alkaline conditions. P-removal here is based on a precipitation process with calcium, as confirmed by Scanning Electron Microscopy-Energy Dispersive Spectroscopy (SEM-EDS) analysis [36].

The industry for mining and processing marble produces large amounts of waste, including a powder containing valuable minerals that can be used in the process for binding $P$ from wastewater. The material in question has been analysed in its natural and calcined forms, and Table 9 presents the results. The sorption capacity of powdered marble can reach $103.20 \mathrm{~g} \mathrm{P} / \mathrm{kg}$ for the natural material and as high as $181.20 \mathrm{~g} \mathrm{P} / \mathrm{kg}$ when calcined at $1000{ }^{\circ} \mathrm{C}$ [37]. On the other hand, work using a Continuous Stirred Tank Reactor (CSTR) documented a $17.00 \mathrm{~g} \mathrm{P} / \mathrm{kg}$ sorption capacity for natural marble powder [38]. Research on industrial wastewater $(\mathrm{pH}=4.76$, initial concentration $1000 \mathrm{mg} \mathrm{P} / \mathrm{L})$, using a process involving calcined powdered marble, found a value for the remaining phosphorus equal to only $341.40 \mathrm{mg} \mathrm{P} / \mathrm{L}$ [37].

Other trials with industrial wastewater $(\mathrm{pH}=6.2$, initial $\mathrm{P}$ concentration $226.34 \mathrm{mg} / \mathrm{L})$ confirm a 99.9\% efficient removal by calcined marble, where the original dosed material was $11.00 \mathrm{~g} \mathrm{P} / \mathrm{L} \mathrm{[39].}$ Eljamal et al. [40] obtained a removal efficiency of $93.0 \%$ with marble dust and synthetic solutions ( $5 \mathrm{~g}$ material $+100 \mathrm{~mL}$ solution at an initial concentration of $100 \mathrm{mg} \mathrm{P} / \mathrm{L}$, shaken for $120 \mathrm{~h}$ at $120 \mathrm{rpm}$ ). 
Table 9. The sorption capacities of marble under different process conditions.

\begin{tabular}{|c|c|c|c|c|c|c|c|}
\hline References & Material & $\begin{array}{c}\text { Initial } \\
\text { Phosphorus } \\
\text { Concentration } \\
{[\mathrm{mg} \mathrm{P} / \mathrm{L}]}\end{array}$ & $\begin{array}{c}\text { Diameter } \\
d_{50} \\
{[\mu \mathrm{m}]}\end{array}$ & $\begin{array}{r}\mathrm{Cor} \\
\mathrm{CaO}[\end{array}$ & $\begin{array}{l}\text { ion } \\
\mathrm{O}[\%]\end{array}$ & $\underset{[-]}{\text { Final }} \mathbf{p H}$ & $\begin{array}{l}\text { Sorption } \\
\text { Capacity } \\
\text { [g P/kg] }\end{array}$ \\
\hline \multirow{2}{*}{ [37] } & marble ${ }^{(*)}$ & 1000 & 32.1 & 46.10 & 1.24 & 9.45 & 103.20 \\
\hline & $\begin{array}{l}\text { calcined } \\
\text { marble }^{(* *)}\end{array}$ & 1000 & 28.9 & 67.45 & 2.35 & 12.27 & 181.20 \\
\hline [38] & marble ${ }^{(* * *)}$ & 100 & 22.6 & 46.06 & 1.24 & - & 17.00 \\
\hline
\end{tabular}

${ }^{(*)}$ Description of the study: $1 \mathrm{~g}$ material $+100 \mathrm{~mL}$ solution, shaken at $400 \mathrm{rpm}$ for $16 \mathrm{~h}, \mathrm{pH}=5.0,{ }^{(* *)}$ Description of the study: $1 \mathrm{~g}$ material $+100 \mathrm{~mL}$ solution, shaken at $400 \mathrm{rpm}$ for $3 \mathrm{~h}, \mathrm{pH}=5.0,{ }^{(* *)}$ Description of the study: reactor CSTR: dose of material $12 \mathrm{~g} / \mathrm{L}$, contact time $8.8 \mathrm{~h}$.

Opoka is another sorbent valued for its ability to absorb phosphorus. Research on opoka has analysed its natural form as well as its form when calcined at various temperatures (Table 10) [41-46], with both types tested on synthetic solutions containing phosphorus. Thermal treatment increased the sorption capacity significantly due to the presence of calcium carbonate decomposition products such as calcium oxide and carbon dioxide. The calcined opoka achieved a high efficiency of phosphorus removal (12.30-181.81 g P/kg). However, a relevant problem in real-life wastewater treatment might be the increased $\mathrm{pH}$ due to calcination, which can exceed 12.0. The thermal treatment of opoka also has an unfavourable economic impact, though a commercial product called Polonite ${ }^{\circledR}$ (a 2.0-6.0 mm opoka fraction calcined at $900^{\circ} \mathrm{C}$ ) is already used to remove $\mathrm{P}$ from both wastewater and water from cultivated fields.

Table 10. Comparison of the sorption capacity of opoka, depending on the method of calcination.

\begin{tabular}{cccccc}
\hline References & Material & $\begin{array}{c}\mathbf{p H} \\
{[-]}\end{array}$ & $\begin{array}{c}\text { The Ratio of } \\
\text { Components SiO } / \mathbf{C a O} \\
{[\%] /[\%]}\end{array}$ & $\begin{array}{c}\text { Fraction } \\
{[\mathbf{m m}]}\end{array}$ & $\begin{array}{c}\text { Sorption Capacity } \\
\text { [g P/kg] }\end{array}$ \\
\hline$[47]$ & Opoka & 8.3 & $34.00 / 28.00$ & $0.25-2.00$ & 0.10 \\
{$[41]$} & Opoka & 6.8 & $44.65 / 23.75$ & 0.25 & 19.60 \\
{$[42]$} & Calcinated opoka at $900^{\circ} \mathrm{C}$ & - & $57.24 / 23.86$ & $0.05-20$ & 12.30 \\
{$[41]$} & Calcinated opoka at $1000^{\circ} \mathrm{C}$ & 12.0 & $39.36 / 42.07$ & 0.25 & 119.60 \\
{$[43]$} & Calcinated opoka at $900^{\circ} \mathrm{C}$ & 12.4 & $66.57 / 30.91$ & dust & 79.37 \\
{$[43]$} & Calcinated opoka at $900^{\circ} \mathrm{C}$ & 12.4 & $45.00 / 58.76$ & dust & 181.82 \\
\hline
\end{tabular}

Sands used as a filtration material can also achieve the surface retention of phosphorus. In filter beds, binding mainly occurs via adsorption and precipitation with calcium, aluminium, and iron (Table 11). Where $\mathrm{pH}$ values are above 6.0, the method of binding phosphorus is based on physical adsorption on iron and aluminium oxides and precipitation precipitation to form sparingly soluble calcium phosphates. In contrast, where the $\mathrm{pH}$ is below 6.0, the precipitation of iron and aluminium phosphates (strengite, variscite) increases as the $\mathrm{pH}$ decreases [48]. A possible explanation for the above reactions can be found in research on phosphorus removal in Constructed Wetlands (CWs) [49]. The phosphorus adsorption on sands is controlled by the interactions of the following parameters: redox potential, $\mathrm{pH}, \mathrm{Fe}, \mathrm{Al}$, and $\mathrm{Ca}$. In an acidic reaction, phosphorus is adsorbed on hydrated $\mathrm{Fe}$ and $\mathrm{Al}$ oxides and can precipitate as insoluble iron and aluminium phosphates. However, precipitation as insoluble calcium phosphate can occur only at $\mathrm{pH}$ values higher than $7.0[49,50]$. This decreasing redox potential can cause the conversion of crystalline $\mathrm{Al}$ and $\mathrm{Fe}$ to an amorphous form. Amorphous hydrated iron and aluminium oxides have a higher sorption capacity than crystalline oxides due to their greater number of individually coordinated surface hydroxyl ions. The mechanism of phosphorus binding entails the exchange of ligands where phosphate displaces water or hydroxyl from the surface of hydrated iron or aluminium oxides to form monodentate and bi-nuclear complexes in the sphere of hydrated oxide coordination [49]. Because the sand's ability to absorb phosphorus may depend on its $\mathrm{Ca}, \mathrm{Al}$, and Fe content, attempts were made to improve the phosphorus removal efficiency of CWs by enriching the sand bed with calcium or iron. The research results have shown that the use 
of a substrate with a high content of iron and aluminium is effective only during the first months of operation [50]. Studies have also shown that the addition of reactive $\mathrm{Ca}\left(\mathrm{CaO}\right.$ or $\left.\mathrm{Ca}(\mathrm{OH})_{2}\right)$ is more effective in improving the adsorption capacity of $\mathrm{P}$ than the addition of $\mathrm{Al}$ and $\mathrm{Fe}[41,47,50]$.

According to Arias et al. [51], the maximum sorption capacities estimated using the Langmuir model do not correspond to or correlate with the actual amounts of P removed in column experiments. Although the Langmuir model is intended to describe adsorption alone, Veith et al. [52] revealed that the equation can describe precipitation reactions whose conditions are defined and isolated appropriately. This confirms that more complex reactions occur in sands [51]. In turn, the research conducted by Vohla et al. [53] showed the efficiency of phosphorus removal at the level of $24.0 \%$ obtained along with a sorption capacity of $1.90 \mathrm{~g} \mathrm{P} / \mathrm{kg}$.

Table 11. Properties of sands in removing phosphorus from wastewater.

\begin{tabular}{|c|c|c|c|c|c|c|c|c|c|}
\hline \multirow{2}{*}{ References } & \multicolumn{2}{|c|}{$\begin{array}{l}\text { Diameter } \\
\text { Material } \\
\text { Grains }\end{array}$} & \multirow{2}{*}{$\mathrm{CaO}[\%]$} & \multirow{2}{*}{\multicolumn{2}{|c|}{$\begin{array}{c}\text { Composition } \\
\mathrm{MgO}[\%] \mathrm{Fe}_{2} \mathrm{O}_{3}[\%]\end{array}$}} & \multirow{2}{*}{$\mathrm{Al}_{2} \mathrm{O}_{3}[\%]$} & \multirow{2}{*}{$\begin{array}{c}\text { Sorption Capacity at } \\
\text { Initial Concentration } \\
320 \mathrm{mg} \mathrm{P} / \mathrm{L} \\
{[\mathrm{g} \mathrm{P} / \mathrm{kg}]}\end{array}$} & \multirow{2}{*}{$\begin{array}{c}\text { Maximum Sorption } \\
\text { Capacity According } \\
\text { to the Langmuir } \\
\text { Model }^{(*)}[\mathrm{g} \mathrm{P} / \mathrm{kg}]\end{array}$} & \multirow{2}{*}{$\begin{array}{c}\text { Phosphorus Removal } \\
\text { Efficiency in a Column } \\
\text { Experiment }{ }^{(* *)} \\
{[\mathrm{g} \mathrm{P} / \mathrm{kg}]}\end{array}$} \\
\hline & $\begin{array}{c}\mathrm{d}_{60} \\
{[\mathrm{~mm}]}\end{array}$ & $\begin{array}{c}\mathrm{d}_{10} \\
{[\mathrm{~mm}]}\end{array}$ & & & & & & & \\
\hline \multirow{3}{*}{ [51] } & 3.20 & 0.80 & 9.79 & 0.35 & 0.68 & 0.48 & 2.68 & 0.061 & 0.134 \\
\hline & 0.60 & 0.21 & 4.90 & 0.17 & 0.52 & 0.45 & 1.68 & 0.130 & 0.117 \\
\hline & 3.40 & 0.61 & 8.72 & 0.21 & 0.51 & 0.36 & 3.94 & 0.064 & 0.165 \\
\hline
\end{tabular}

$\left(^{*}\right)$ Description of the study: $100 \mathrm{~mL}$ solutions with initial concentrations of $2.5-300 \mathrm{mg} \mathrm{P} / \mathrm{L}+5 \mathrm{~g}$ material, shaken for $20 \mathrm{~h},{ }^{(*)}$ Description of the study: solution with initial concentration of $10 \mathrm{mg}$ P/L, flow $240 \mathrm{~mL} / \mathrm{d}$, time $20 \mathrm{~h} / \mathrm{d}$ for 12 weeks.

Limestone is another material used to remove phosphorus. Research by Johansson et al. [44] showed limestone to have a phosphorus sorption capacity of $0.25 \mathrm{~g} \mathrm{P} / \mathrm{kg}$, while Drizo et al. [14] gave a value of $0.68 \mathrm{~g} \mathrm{P} / \mathrm{kg}$. The highest observed value was $1.09 \mathrm{~g} \mathrm{P} / \mathrm{kg}$, obtained by Bellier et al. [54] (Table 12). The reported efficiency of phosphorus removal was 73.0-93.0\% [54,55]. Further, Li et al. [56] analysed the impact of individual factors on limestone's adsorption of $\mathrm{P}$ using a series of periodic experiments, showing increased removal efficiency with both temperature and contact time. However, where the initial concentration was higher, the process was less efficient. The size of the fraction had no significant impact, and the authors observed the maximum efficiency (above $90.0 \%$ ) at a pH below 6.4, while $\mathrm{pH}$ values higher than 8.15 were associated with reduced efficiency [56].

Table 12. Analysis of sorption by limestone.

\begin{tabular}{|c|c|c|c|c|}
\hline References & Description of the Study: & $\begin{array}{l}\text { Fraction } \\
{[\mathrm{mm}]}\end{array}$ & $\begin{array}{l}\mathrm{pH} \\
{[-]}\end{array}$ & $\begin{array}{c}\text { Maximum Sorption } \\
\text { Capacity According to } \\
\text { the Langmuir Model } \\
{[\mathrm{g} \mathrm{P} / \mathrm{kg}]}\end{array}$ \\
\hline [14] & $\begin{array}{l}\text { solutions with initial concentrations } \\
\text { of } 2.5-40 \mathrm{mg} \mathrm{P} / \mathrm{L}+20 \mathrm{~g} \text { material, } \\
\text { shaken at } 60 \mathrm{rpm} \text { for } 24 \mathrm{~h}\end{array}$ & 12.7 & 7.8 & 0.68 \\
\hline [47] & $\begin{array}{l}\text { solutions with initial concentrations } \\
\text { of } 5-25 \mathrm{mg} \mathrm{P} / \mathrm{L}+1 \mathrm{~g} \text { material }\end{array}$ & $0.3-2.0$ & 8.9 & 0.25 \\
\hline [54] & $\begin{array}{l}\text { solutions with initial concentrations } \\
\text { of } 5-150 \mathrm{mg} \mathrm{P} / \mathrm{L}+1 \mathrm{~g} \text { material, } \\
\text { shaken at } 160 \mathrm{rpm} \text { for } 24 \mathrm{~h}\end{array}$ & $\mathrm{~d}_{60}: 7.0 \mathrm{~d}_{10}: 3.5$ & - & 1.09 \\
\hline
\end{tabular}

Wollastonite is another reactive material in which the $\mathrm{Ca} / \mathrm{Mg}$ sorption group predominates. Previous studies showed that when the initial concentration is lower, the sorption capacity is reduced drastically. This likely precludes the use of wollastonite in wastewater treatment [57] (Table 13). Removal efficiency is satisfactory when concentrations of $\mathrm{P}$ are higher, with $51.1 \%$ achieved in column experiments with $5 \mathrm{mg} \mathrm{P} / \mathrm{L}$ [58]. Static experiments reported 90.0-93.0\% efficiency with P concentrations of $14-61 \mathrm{mg} / \mathrm{L}$ [57]. 
Table 13. Properties of wollastonite for phosphorus removal.

\begin{tabular}{|c|c|c|c|c|c|c|c|}
\hline References & \multicolumn{4}{|c|}{$\begin{array}{c}\text { Composition } \\
\mathrm{CaO}[\%] \mathrm{MgO}[\%] \mathrm{Fe}_{2} \mathrm{O}_{3}[\%] \mathrm{Al}_{2} \mathrm{O}_{3}[\%]\end{array}$} & \multirow{2}{*}{$\begin{array}{c}\begin{array}{c}\text { Initial } \\
\text { Phosphorus } \\
\text { Concentration } \\
\text { [mg P/L] }\end{array} \\
0.8-1700\end{array}$} & \multirow{2}{*}{$\begin{array}{c}\begin{array}{c}\text { Sorption } \\
\text { Capacity } \\
\text { [g P/kg] }\end{array} \\
\begin{array}{c}0.0001-12.000 \\
(*)\end{array}\end{array}$} & \multirow{2}{*}{$\begin{array}{c}\text { Phosphorus } \\
\text { Removal } \\
\text { Efficiency [\%] } \\
-\end{array}$} \\
\hline [57] & 46.00 & 0.47 & 0.07 & - & & & \\
\hline & & & & & $14-61$ & - & $90.0-93.0^{(*)}$ \\
\hline [58] & 21.14 & 2.21 & 3.07 & 10.31 & 5 & - & $51.1^{(* *)}$ \\
\hline
\end{tabular}

(*) Description of the study: $75 \mathrm{~mL}$ solutions with initial concentrations of $0.8-1700 \mathrm{mg} \mathrm{P} / \mathrm{L}+10 \mathrm{~g}$ material, shaken at $200 \mathrm{rpm}$ for $0.5-20 \mathrm{~h},{ }^{(* *)}$ Description of the study: column experiment: solution with an initial concentration of $5 \mathrm{mg} \mathrm{P} / \mathrm{L}$; flow $610 \mathrm{~L} / \mathrm{m}^{2}$ for 68 weeks.

The use of gravel in filtration systems likewise reflects the capacity to bind phosphorus, as $\mathrm{Ca}$, $\mathrm{Al}$, and $\mathrm{Fe}$ engage in adsorption and precipitation reactions. Sorption properties differ according to the content of these compounds (Table 14 offers a characterisation of these compounds according to the literature data). According to Vohla et al. [53], gravel has sorption capacities of 1.20-1.70 g P/kg. However, Mann et al. [59] only arrived at figures of $0.026-0.048 \mathrm{~g} \mathrm{P} / \mathrm{kg}$ - a reflection of the low content of Fe and $\mathrm{Al}$ ions in their material compared to the material tested by Vohla et al. [53]. Gravel of a lower fraction-size was also found to remove more phosphorus [53].

Table 14. Analysis of gravel sorption.

\begin{tabular}{|c|c|c|c|c|c|c|c|}
\hline References & \multicolumn{4}{|c|}{$\begin{array}{c}\text { Composition } \\
\mathrm{CaO}[\%] \mathrm{MgO}[\%] \mathrm{Fe}_{2} \mathrm{O}_{3}[\%] \mathrm{Al}_{2} \mathrm{O}_{3}[\%]\end{array}$} & \multirow{2}{*}{$\begin{array}{c}\begin{array}{c}\text { Fraction } \\
\text { [mm] }\end{array} \\
5.0-10.0\end{array}$} & \multirow{2}{*}{$\begin{array}{c}\begin{array}{c}\text { Sorption } \\
\text { Capacity } \\
\text { [g P/kg] }\end{array} \\
0.0258\end{array}$} & \multirow{2}{*}{$\begin{array}{c}\begin{array}{c}\text { Phosphorus } \\
\text { Removal } \\
\text { Efficiency [\%] }\end{array} \\
-\end{array}$} \\
\hline$[50]\left({ }^{*}\right)$ & - & 0.08 & 0.78 & 0.40 & & & \\
\hline$[59] 11$ & - & 0.01 & 0.39 & 4.50 & $3.0-5.0$ & 0.0478 & - \\
\hline \multirow{2}{*}[53]{$^{(* *)}$} & 19.60 & 6.80 & 1.12 & 0.66 & $0.9-1.8$ & 1.20 & 32.6 \\
\hline & 2.80 & 1.99 & 1.37 & 0.94 & $0.07-1.0$ & 1.70 & 50.3 \\
\hline
\end{tabular}

${ }^{(*)}$ Description of the study: $40 \mathrm{~mL}$ solutions with initial concentrations of 5-100 mg P/L $+20 \mathrm{~g}$ material, shaken at $1500 \mathrm{rpm}$ for $24,30 \mathrm{~h},{ }^{(* *)}$ Description of the study: $75 \mathrm{~mL}$ solutions with initial concentrations of $5-100 \mathrm{mg} \mathrm{P} / \mathrm{L}+3 \mathrm{~g}$ material, shaken for $24 \mathrm{~h}$.

Reactive materials also include raw materials from the sea, such as oyster shells, clams, and crushed coral, which represent renewable sources of $\mathrm{CaCO}_{3}$. The materials researched by Zapater-Pereyra et al. [60] were used in raw form but also followed a pyrolysis process at $750{ }^{\circ} \mathrm{C}$. Their experiments were performed on $500 \mathrm{~mL}$ solutions of phosphorus compounds, with $10 \mathrm{~g}$ of material, and the solutions were shaken at $100 \mathrm{rpm}$ for 7 days. Materials previously subjected to pyrolysis were immediately capable of removing all phosphorus, with the efficiency of the process reaching $99.0 \%$. The raw materials showed markedly lower efficiency-12.0-17.0\%-after 12 days. Changes in $\mathrm{pH}$ following the mixing of the marine materials with a source of phosphorus were also investigated. The $\mathrm{pH}$ proved stable for raw materials (in the range of 7.1-7.8), while pyrolysis of the marine material indicated an increase in $\mathrm{pH}$ to 12.0. Studies further showed that an increase in $\mathrm{pH}$ to 12.0, achieved by adding $\mathrm{NaOH}$ to a solution, also immediately increases the efficiency of the phosphorus-removal process. Ultimately, the performance attained was similar to that with pyrolysed materials.

Research indicates that natural materials mainly remove $\mathrm{P}$ via an adsorption process, while heat-treated materials (with their relevant high-pH conditions) exert their main effects via precipitation. While the process for removing $\mathrm{P}$ may be highly efficient, the tested marine raw materials are likely to have limited involvement in wastewater treatment due to the need for the $\mathrm{pH}$ to be adjusted later $[60,61]$. Other research on the sorption capacity of powdered sun corals (with high concentrations of calcium carbonate) has studied raw sun corals (RSC), corals modified physically (SCA), and corals modified chemically (SCC) [62]. The maximum sorption capacities found for these three were 6.83, 7.06, and $9.60 \mathrm{~g} \mathrm{P} / \mathrm{kg}$, respectively [62]. The group of marine materials able to bind phosphorus also includes "shell sand", a naturally occurring carbonate material (which also includes some worn-down coral). 
As Table 15 shows, shell sand has been reported to have sorption capacities of $3.00-17.00 \mathrm{~g} \mathrm{P} / \mathrm{kg}$, which was confirmed by Sovik et al. [63] with values of $0.80-8.00 \mathrm{~g} \mathrm{P} / \mathrm{kg}$ (against initial P concentrations of 5-1500 mg/L). The shell-sand analysis developed by Adam et al. [64] indicates that the lower the initial concentration is (across a range of $10-15 \mathrm{mg} \mathrm{P} / \mathrm{L}$ ), the lower the efficiency of $\mathrm{P}^{\prime}$ s removal. Conversely, the higher the initial concentration is (across a range of $50-480 \mathrm{mg} \mathrm{P} / \mathrm{L}$ ), the higher the removal efficiency. The different sorption capacities obtained by Roseth et al. [65] likely resulted from the dissolution of calcium phosphate.

Column experiments have confirmed the efficiency achieved by shell sand to be around $3.50 \mathrm{~g}$ $\mathrm{P} / \mathrm{kg}$ [65]. Studies using the powdered shells of freshwater clams by Xiong et al. [66] revealed that calcining the material at $700{ }^{\circ} \mathrm{C}$ for $20 \mathrm{~min}$ increases the material's capacity to remove phosphate by $25.0 \%$ to $55.0 \%$ (at pH 5.5). For adsorption isotherm testing, the Temkin and D-R equations have been applied to all three shell types, indicating chemical adsorption. The maximum phosphorus adsorption capacity of natural clam shells is $6.95 \mathrm{~g} \mathrm{P} / \mathrm{kg}$, while the removal efficiency for calcined and natural materials is $58.23 \%$ and $26.04 \%$, respectively, at $\mathrm{pH} 5.5$ [66].

Table 15. Research on the adsorption of phosphorus by shell sand.

\begin{tabular}{|c|c|c|c|c|c|c|c|}
\hline \multirow{2}{*}{$\begin{array}{c}\text { References } \\
{[65]}\end{array}$} & Material & \multicolumn{4}{|c|}{$\begin{array}{c}\text { Composition } \\
\mathrm{CaO}[\%] \mathrm{MgO}[\%] \mathrm{Fe}_{2} \mathrm{O}_{3}[\%] \mathrm{Al}_{2} \mathrm{O}_{3}[\%]\end{array}$} & \multirow{2}{*}{$\begin{array}{c}\text { Sorption } \\
\text { Capacity } \\
\text { [g P/kg] } \\
14.00-17.00^{(*)} \\
3.00-4.00^{(* *)}\end{array}$} & \multirow{2}{*}{$\begin{array}{c}\text { Phosphorus } \\
\text { Removal } \\
\text { Efficiency in a } \\
\text { Column } \\
\text { Experiment [\%] } \\
-\end{array}$} \\
\hline & $\begin{array}{c}\text { powdered shell } \\
\text { sand }\end{array}$ & $39.00-42.00$ & $0.60-3.20$ & - & - & & \\
\hline \multirow[t]{2}{*}{ [66] } & $\begin{array}{l}\text { natural powdered } \\
\text { shells }\end{array}$ & 52.60 & 0.20 & 0.15 & 0.14 & 6.95 & 26.0 \\
\hline & $\begin{array}{c}\text { pyrolyzed } \\
\text { powdered shells }\end{array}$ & 55.20 & 0.21 & 0.03 & 0.08 & - & 58.2 \\
\hline [64] & shell sand & - & - & - & - & 9.60 & 97.0 \\
\hline
\end{tabular}

${ }^{(*)}$ Description of the study: $75 \mathrm{~mL}$ solutions with initial concentrations of 0-1000 mg P/L $+3 \mathrm{~g}$ material, shaken for $24 \mathrm{~h},{ }^{(*)}$ Description of the study: $75 \mathrm{~mL}$ solutions with initial concentrations of $5-1000 \mathrm{mg} \mathrm{P} / \mathrm{L}+3 \mathrm{~g}$ material, shaken for $48 \mathrm{~h}$.

\section{Synthesized and Waste Materials and Their Modifications}

Research into the use of waste materials agrees with the model of the circular economy, which assumes that manufactured products, as well as their raw materials, should remain in the economy for as long as possible, minimising the amount of waste generated [67]. Slag is waste from metallurgical processes involving metals, mainly steel and iron. Table 16 presents the test results for various types of slag according to their capacity to remove phosphorus. In a study by $\mathrm{Xu}$ et al. [68], the maximum sorption capacity determined for furnace slag, in line with the Langmuir model, was $8.89 \mathrm{~g} \mathrm{P} / \mathrm{kg}$. Using column research, Dunets et al. [69] arrived at a similar value of $8.80 \mathrm{~g} \mathrm{P} / \mathrm{kg}$ for furnace slag (where the initial concentration of P was $60 \mathrm{mg} / \mathrm{L}$ ). Other work on steel slag modified by high-powered ball-grinding from Li et al. [70] found adsorption capacities between 1.06 and $18.88 \mathrm{~g} \mathrm{P} / \mathrm{kg}$, where phosphorus concentrations were 1-20 mg P/L. In contrast, according to Oguz [71], blast-furnace slag, as a by-product formed when iron ore is smelted, has $6.37 \mathrm{~g} / \mathrm{kg}$ efficiency for binding phosphorus when the element is present at a concentration of $500 \mathrm{mg} / \mathrm{L}$. The hydrated calcium silicate (CHS) obtained from blast-furnace slag has emerged as a very good phosphorus adsorbent. When initial concentrations are $38.0-47.5 \mathrm{mg} \mathrm{P} / \mathrm{L}$, this material can achieve a maximum adsorption capacity of $53.11 \mathrm{~g} \mathrm{P} / \mathrm{kg}$. This adsorbent is particularly promising for wastewater and water since it exerts activity even when the phosphate concentration is low and has tolerance to a wide range of $\mathrm{pH}$ values [72]. However, Yasipourtehrani et al. [73] reported that samples of blast-furnace slag involved in the process release various concentrations of the toxic metals $\mathrm{Al}, \mathrm{Cd}, \mathrm{Co}$, and $\mathrm{Hg}$ into solutions, a factor that could severely limit the material's application in treatment. 
Table 16. Sorption properties of different varieties of slag.

\begin{tabular}{|c|c|c|c|c|c|}
\hline Material [References] & $\begin{array}{l}\mathrm{pH} \\
{[-]}\end{array}$ & $\begin{array}{c}\text { Initial } \\
\text { Phosphorus } \\
\text { Concentration } \\
{[\mathrm{mg} \mathrm{P} / \mathrm{L}]}\end{array}$ & $\begin{array}{l}\text { Sorption } \\
\text { Capacity } \\
{[\mathrm{g} \mathrm{P} / \mathrm{kg}]}\end{array}$ & $\begin{array}{l}\text { Maximum } \\
\text { Sorption } \\
\text { Capacity [g } \\
\text { P/kg] }\end{array}$ & $\begin{array}{c}\text { Phosphorus } \\
\text { Removal } \\
\text { Efficiency } \\
{[\%]}\end{array}$ \\
\hline Furnace slag [68] ${ }^{(*)}$ & 12.3 & $100-1000$ & - & $8.89^{(\mathrm{L})}$ & - \\
\hline Steel slag [70] ${ }^{(* *)}$ & - & $1-20$ & $1.06-18.88$ & 21.70 & 98.2 \\
\hline Blast furnace slag [71] $]^{(* * *)}$ & 8.5 & 500 & - & $6.37^{(\mathrm{F})}$ & 99.0 \\
\hline $\begin{array}{l}\text { CSH from blast furnace } \\
\text { slag [72] }]^{(* * *)}\end{array}$ & 12 & $38-47.5$ & 53.11 & $75.70^{(\mathrm{L})}$ & - \\
\hline Furnace slag [69] ${ }^{(* * * *)}$ & $\begin{array}{l}11 \\
11\end{array}$ & $\begin{array}{l}60 \\
20\end{array}$ & $\begin{array}{l}8.80 \\
1.64\end{array}$ & $\begin{array}{l}- \\
-\end{array}$ & $\begin{array}{l}99.0 \\
99.0\end{array}$ \\
\hline \multicolumn{6}{|c|}{ 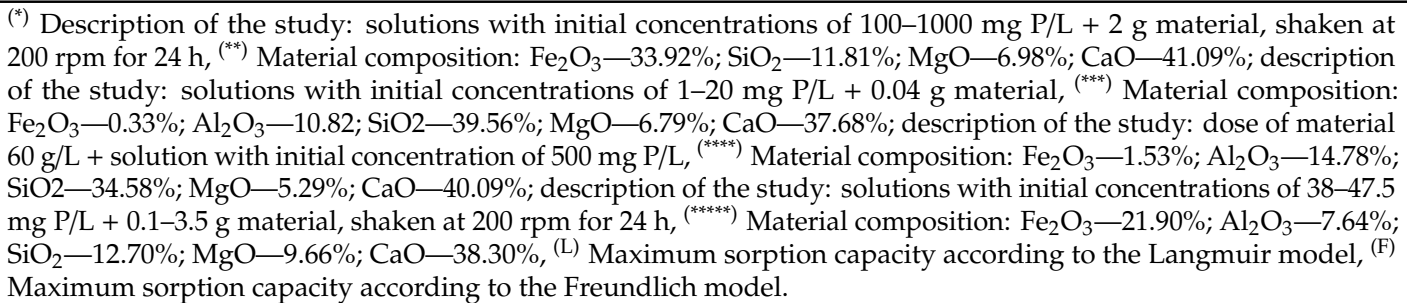 } \\
\hline
\end{tabular}

Biochar, which is obtained through biomass pyrolysis, is characterised by a loose porous structure that encourages its use as a soil improver. It also has applications in wastewater treatment and environmental protection due to its adsorption and cation-exchange properties. Research by Qiu et al. [74] on modified biocarbon (pine wood subjected to pyrolysis at $500{ }^{\circ} \mathrm{C}$ in the presence of fly ash and gangue) found that modification increased both the specific surface area and the adsorbent capacity (Table 17). Analysis of the adsorption kinetics showed that the highest phosphorus binding rate was attained by biochar with gangue. The kinetics were described using pseudo-first-order and pseudo-second-order kinetic models, though the fit was better with the latter, indicating amounts of adsorbed phosphorus of $1.80-2.17 \mathrm{~g} \mathrm{P} / \mathrm{kg}$. The maximum adsorption capacity according to the Langmuir model was $2.39 \mathrm{~g} \mathrm{P} / \mathrm{kg}$ for biochar only, $3.08 \mathrm{~g} \mathrm{P} / \mathrm{kg}$ when fly ash was also used, and $3.20 \mathrm{~g}$ $\mathrm{P} / \mathrm{kg}$ with gangue [74].

Zhu et al. [75] obtained biochar coated with $\mathrm{MgO}$ nanoparticles by applying pyrolysis of $\mathrm{MgCl}_{2}$-impregnated corn straw. The adsorption process was best described using the Langmuir-Freundlich model, with a maximum sorption capacity of $60.95 \mathrm{~g} \mathrm{P} / \mathrm{kg}$ recorded. The kinetic analysis of biochar with $\mathrm{MgO}$ under different processing times indicated that phosphate adsorption on this material was mainly controlled by rapid binding with an external surface (about $75 \%$ of the adsorption equilibrium), while the rate was limited by the slow diffusion of phosphate into the biochar (about $25 \%$ of the adsorption equilibrium). The analysed dolomite-modified biochar was characterised by a maximum adsorption capacity of $29.18 \mathrm{~g} \mathrm{P} / \mathrm{kg}$ [76].

Lama et al. [77] experimented with coal slag, a by-product of thermal power plants. The particle size in this case was about $50 \mu \mathrm{m}$, while the SSA value was $9.20 \mathrm{~m}^{2} / \mathrm{g}$. The maximum sorption capacity was $21.63 \mathrm{~g} \mathrm{P} / \mathrm{kg}$, while the concentration range for $\mathrm{P}$ was $0-30 \mathrm{mg} / \mathrm{L}$, and the other conditions included $\mathrm{pH}$ 6, an adsorbent dose equal to $0.1 \mathrm{~g}$, and a contact time of $45 \mathrm{~min}$.

The literature on static adsorption gives a maximum sorption capacity of fly ash equal to $0.86 \mathrm{~g}$ $\mathrm{P} / \mathrm{kg}$ (with $20 \mathrm{~g}$ of material and solutions with concentrations between 2.5 and $40 \mathrm{mg} \mathrm{P} / \mathrm{L}$ ). The same authors, running a column experiment (with initial concentrations of $35-45 \mathrm{mg} \mathrm{P} / \mathrm{L}$ and a process duration of 40 days), obtained a saturation of the material with phosphorus at a level of $0.30 \mathrm{~g}$ $\mathrm{P} / \mathrm{kg}$ [14]. Research by Oguz [78] further showed that fly ash's phosphorus sorption capacity (with a $0.12-0.002 \mathrm{~mm}$ fraction and $0.52 \mathrm{~m}^{2} / \mathrm{g} \mathrm{SSA}$ ) is greater with a higher temperature, mixing speed, $\mathrm{pH}$, and phosphorus concentration in the solution. Fly ash has the ability to adsorb up to $71.87 \mathrm{~g} \mathrm{P} / \mathrm{kg}$ at an initial concentration of phosphorus equal to $130 \mathrm{mg} \mathrm{P} / \mathrm{L}$ [78]. Research conducted by Xu et al. [68] gave a maximum sorption capacity for this material of $8.81 \mathrm{~g} \mathrm{P} / \mathrm{kg}$ (with $2 \mathrm{~g}$ of material + a solution 
with an initial concentration of 100-1000 mg P/L, shaken for $24 \mathrm{~h}$ at $200 \mathrm{rpm}$ ), which is in line with the Langmuir equation.

Table 17. The sorption capacities of modified biochar and coal slag.

\begin{tabular}{|c|c|c|c|c|c|c|c|c|c|c|}
\hline \multirow[b]{2}{*}{ References } & \multirow{2}{*}{\multicolumn{2}{|c|}{ Material }} & \multicolumn{5}{|c|}{ Composition } & \multirow{2}{*}{$\begin{array}{c}\text { Specific } \\
\text { Surface } \\
\text { Area } \\
{\left[\mathrm{m}^{2} / \mathrm{g}\right]}\end{array}$} & \multirow{2}{*}{$\begin{array}{l}\text { Sorption Capacity } \\
\text { According to the } \\
\text { Kinetic Model [g } \\
\text { P/kg] }\end{array}$} & \multirow{2}{*}{$\begin{array}{l}\text { Maximum Sorption } \\
\text { Capacity According } \\
\text { to the Langmuir } \\
\text { Model }[\mathrm{g} \mathrm{P} / \mathrm{kg}]\end{array}$} \\
\hline & & & $\begin{array}{c}\mathrm{Fe}_{2} \mathrm{O}_{3} \\
{[\%]}\end{array}$ & $\begin{array}{c}\mathrm{Al}_{2} \mathrm{O}_{3} \\
{[\%]}\end{array}$ & $\begin{array}{c}\mathrm{SiO}_{2} \\
{[\%]}\end{array}$ & $\begin{array}{l}\mathrm{CaO} \\
{[\%]}\end{array}$ & $\underset{[\%]}{\mathrm{MgO}}$ & & & \\
\hline \multirow{3}{*}{ [72] } & \multirow{3}{*}{ biochar } & \multirow{3}{*}{$\begin{array}{c}\text { raw } \\
\text { with fly ash } \\
\text { with coal } \\
\text { gangue }\end{array}$} & - & - & - & - & - & 61.16 & 1.80 & 2.39 \\
\hline & & & 8.36 & 33.26 & 41.96 & 4.88 & 0.50 & 80.72 & 2.11 & 3.08 \\
\hline & & & 8.23 & 31.66 & 40.80 & 9.66 & 0.66 & 75.86 & 2.17 & 3.20 \\
\hline [77] & \multirow{3}{*}{\multicolumn{2}{|c|}{$\begin{array}{c}\text { coal slag } \\
\text { biochar containing } \mathrm{MgO} \\
\text { nanoparticles } \\
\text { dolomite-modified } \\
\text { biochar }\end{array}$}} & 5.14 & 28.70 & 55.90 & 1.04 & 1.96 & 9.20 & 8.85 & 21.63 \\
\hline [75] & & & - & - & - & - & - & 273.82 & - & 60.95 \\
\hline [76] & & & - & - & - & - & - & 11.31 & 20.48 & 29.18 \\
\hline
\end{tabular}

Autoclaved aerated concrete has been classified as a reactive material for phosphorus removal due to its high lime content. This material's application is also favoured by its high content of tobermorite (a hydrated calcium silicate mineral). The sorption capacity was confirmed by tests showing the material's capacity to reduce the amount of phosphorus by $70-80 \%$ [79]. Table 18 presents the sorption properties of this autoclaved aerated concrete [80-84]. The material has a satisfactory capacity for phosphorus sorption and can thus be used in the treatment of wastewater and water. However, an unfavorable feature is its alkaline $\mathrm{pH}$.

Table 18. Analysed sorption properties of autoclaved concrete.

\begin{tabular}{cccccc}
\hline References & $\begin{array}{c}\text { Fraction } \\
{[\mathrm{mm}]}\end{array}$ & $\begin{array}{c}\text { Initial Phosphorus } \\
\text { Concentration } \\
\text { [mg P/L] }\end{array}$ & $\begin{array}{c}\text { Maximum Sorption } \\
\text { Capacity According to the } \\
\text { Langmuir Model [g P/kg] }\end{array}$ & $\begin{array}{c}\text { Phosphorus } \\
\text { Removal } \\
\text { Efficiency [\%] }\end{array}$ & $\begin{array}{c}\text { Final pH } \\
{[-]}\end{array}$ \\
\hline$[80]^{(*)}$ & $2.0-4.0$ & 10.0 & 70.90 & 100.0 & $8.5-9.3$ \\
{$[82]^{(* *)}$} & $2.0-4.0$ & 100.0 & 14.29 & - & - \\
{$[83]^{(* * *)}$} & $0.125-0.250$ & $0.2-0.3$ & 0.28 & $65.2-86.7$ & $10.3-11.3$ \\
{$[81]^{(* * *)}$} & dust & 25.0 & 7.93 & 94.0 & 12.3 \\
{$[84]^{(* * * *)}$} & $2.0-5.0$ & $4.9-1108.7$ & 9.00 & - & - \\
\hline
\end{tabular}

(*) Material composition: $\mathrm{Fe}_{2} \mathrm{O}_{3}-1.10 \% ; \mathrm{SiO}_{2}-51.40 \% ; \mathrm{CaO}-26.30 \% ; \mathrm{Al}_{2} \mathrm{O}_{3}-1.95 \%$. Phosphorus removal efficiency of $100 \%$ for an initial concentration of $5 \mathrm{mg} \mathrm{P} / \mathrm{L},{ }^{(* *)}$ Description of the study: solution with initial concentration of $100 \mathrm{mg} \mathrm{P} / \mathrm{L}+$ material, shaken at $150 \mathrm{rpm}$ for $4 \mathrm{~h},{ }^{\left({ }^{* *}\right)}$ Description of the study: solutions with initial concentrations of $0.2-0.3 \mathrm{mg} \mathrm{P} / \mathrm{L}+$ material, shaken for $1 \mathrm{~h},{ }^{(* * *)}$ Material composition: $\mathrm{Fe}_{2} \mathrm{O}_{3}-3.06 \% ; \mathrm{SiO}_{2}-20.88 \%$; $\mathrm{CaO}-53.50 \% ; \mathrm{Al}_{2} \mathrm{O}_{3}-6.13 \% ; \mathrm{MgO}-2.39$; description of the study: material + solutions with initial concentrations of $25 \mathrm{mg} \mathrm{P} / \mathrm{L}$, shaken at $150 \mathrm{rpm}$ for $8 \mathrm{~h},{ }^{\left({ }^{* * * *}\right)}$ Material composition: $\mathrm{Fe}_{2} \mathrm{O}_{3}-1.03 \%$; $\mathrm{SiO}_{2}-57.24 \% ; \mathrm{CaO}-24.60 \%$; $\mathrm{Al}_{2} \mathrm{O}_{3}-1.96 \%$; $\mathrm{MgO}-0.52$; description of the study: material + solutions with initial concentrations of 4.87-1108.7 $\mathrm{mg} \mathrm{P} / \mathrm{L}$, shaken for $0.5 \mathrm{~h}$.

Boujelben et al. [85] experimented on the sorption potential of three modified sorbents, synthetic iron oxide-coated sand (SCS), naturally iron oxide-coated sand (NCS), and iron oxide-coated crushed brick (CB). The material analyses (SEM Microscopy) showed that the crushed version differs from the others in having the most micropores and a larger specific surface area due to its clay content. The maximum phosphate sorption capacity at an optimal $\mathrm{pH}$ of 5.0 was $1.50 \mathrm{~g} \mathrm{P} / \mathrm{kg}$ for SCS, $1.80 \mathrm{~g} \mathrm{P} / \mathrm{kg}$ for $\mathrm{CB}$, and $0.88 \mathrm{~g} \mathrm{P} / \mathrm{kg}$ for NCS. The effect of temperature on sorption was also investigated, with the results indicating that adsorption is an endothermic process [85].

Chen et al. [86] tested magnetic nanocomposites (magnetic diatomite (MDC) and aluminium lithium (MIC)) obtained by loading $\mathrm{Fe}_{2} \mathrm{O}_{3}$ nanoparticles onto the raw surfaces of materials using the solvothermal method. The highest adsorption capacity characterized an acidic solution. The adsorption kinetics suggested a pseudo-second-order equation, with limitations on the rate influenced by intramolecular diffusion. The maximum values noted for phosphorus adsorption capacity in MDC and MIC were 11.89 and $5.48 \mathrm{~g} \mathrm{P} / \mathrm{kg}$, respectively. The mechanisms underpinning adsorption are the 
electrostatic attraction between the adsorbent and adsorbate and ligand exchange. MDC and MIC show appropriate selectivity and regenerative capacity for reuse [86].

Ma et al. [87] used inorganic-organic montmorillonites (IOMts) obtained by modifying polyhydroxy-aluminium $\left(\mathrm{Al}_{13}\right)$-pillared montmorillonite (AlPMt) with a cationic surfactant $(\mathrm{C} 16)$ and a zwitterionic surfactant (Z16). Analysis of the phosphorus adsorption process using these materials showed that, for concentrations in the $20-140 \mathrm{mg} \mathrm{P} / \mathrm{L}$ range and a solution with a $\mathrm{pH}$ of 5.0 , the sorption capacity ranged between 10.07 and $13.04 \mathrm{~g} \mathrm{P} / \mathrm{kg}$, depending on the type of modification [87].

Goethite is another reactive material, a version of which was synthesised under laboratory conditions and analysed in studies conducted by Siwek et al. [9]. The adsorption obtained was in the range of $6.10-8.00 \mathrm{~g} \mathrm{P} / \mathrm{kg}$ and better at $10-20^{\circ} \mathrm{C}$ than at $4{ }^{\circ} \mathrm{C}(10 \mathrm{mg}$ of goethite $+25 \mathrm{~mL}$ of a solution at an initial concentration of $10 \mathrm{mg} \mathrm{P} / \mathrm{L}$ ). The process of adsorption described by the Langmuir model entails a maximum sorption capacity for goethite in the range of $18.20-27.00 \mathrm{~g} \mathrm{P} / \mathrm{kg}$, depending on the type of solution. A higher capacity was observed when a solution including natural water from bodies of water affected by eutrophication was used instead of distilled water. This points to the presence of other ions capable of affecting the process by which phosphate ions are inactivated [9]. Goethite is apparently able to bind P effectively over a wide $\mathrm{pH}$ range (from 4.0 to 11.0 ) $[9,88]$.

Maamoun et al. [89] conducted research on permeable reactive barriers (PRBs) with a nano-zero-valent iron (nZVI), which is another putative synthesized material for phosphorus removal from wastewater. Static experiments were conducted at $\mathrm{pH}=7 \pm 0.5$ under anaerobic conditions. Solutions with initial concentrations of 5-1000 mg P/L including $1 \mathrm{~g} / \mathrm{L}$ of nZVI were shaken at $300 \mathrm{rpm}$. The maximum adsorption capacity of nano-ferrous particles for phosphorus was $54.34 \mathrm{~g} \mathrm{P} / \mathrm{kg}$-Fe, while that for the mixture $(1 \%)$ of $\mathrm{Fe} 0+$ river sand was $3.9 \mathrm{~g} \mathrm{P} / \mathrm{kg}$. In addition, the calculated correlation coefficients indicated that the Langmuir isotherm is more appropriate for describing the adsorption process than the Freundlich model. Column experiments were carried out via the in situ method for one month using three columns of sandy soil with different configurations of layers that reacted with the nZVI barriers (column C1: 1 large reactivated layer, column C2: two small reactivated layers, and column C3: river sand without a reactivated layer). Solutions with an initial concentration of $25 \mathrm{mg}$ $\mathrm{P} / \mathrm{L}$ were introduced into the columns, and the leachate was collected for analysis. It was found that two layers of the reactive mixture $\left(\mathrm{Fe}^{0} /\right.$ river sand) offered comparatively better phosphorus removal performance than one combined layer. The highest overall phosphorus removal efficiency (68\%) was achieved for the $\mathrm{C} 2$ column over 29 days of experimentation. The authors noted that the phosphorus removal mechanism of nZVI nano-valent iron barriers could rely on both the chemical adsorption of phosphorus on the iron oxide layer (resulting in hydroxide as a result of corrosion of the core nZVI) and the co-precipitation of iron ions on the surfaces of particles. Due to its high sorption capacity, this material can be successfully used for in situ remediation techniques and also in other technologies for phosphorus removal from wastewater $[89,90]$. Table 19 presents a list of the sorption properties of the synthesized materials.

Table 19. Synthesized materials.

\begin{tabular}{ccc}
\hline Material & Specific Surface Area $\left[\mathbf{m}^{2} / \mathbf{g}\right]$ & $\begin{array}{c}\text { Maximum Sorption Capacity } \\
\text { According to the Langmuir } \\
\text { Model [g P/kg] }\end{array}$ \\
\hline Magnetic diatomite & - & 11.89 \\
nanocomposite (MDC) & - & 5.48 \\
Illite clay nanocomposite (MIC) & 283.20 & $10.07-13.04$ \\
Modified montmorillonite AlPMt & 43.09 & 54.34 \\
Nano-valent iron barriers (nZVI) & 100.00 & $18.20-27.00$ \\
Goethite synthesized & & \\
\hline
\end{tabular}

Portland cement is a type of hydraulic mineral binder obtained by mixing a ground cement clinker with gypsum (acting as a setting time regulator) in an amount up to $5 \%$. Cement clinker is produced by burning (raw) materials containing limestone and aluminosilicates. The basic components of Portland 
cement are mixed in a cement mill, and the material can be clean or multi-component (supplemented with slag or limestone). After determining the respective phosphate binding capacities of these two types, Masłon [91] found both forms promising for use in wastewater technology. Trials with a synthetic solution (initial concentration $1.2 \mathrm{mg} \mathrm{P} / \mathrm{L}$ ) and wastewater (initial concentration $1.7 \mathrm{mg} \mathrm{P} / \mathrm{L}$ ) provided removal efficiency values of 97.2 and $96.3 \%$. On the other hand, testing of the pure cement revealed $95.0 \%$ efficiency with wastewater (initial concentration $1.2 \mathrm{mg} \mathrm{P} / \mathrm{L}$ ) and a corresponding value of $96.8 \%$ for the synthetic solution. Given that both forms of Portland cement proved advantageous, phosphate removal was deemed to be based mainly on the lime-precipitation principle. However, the usefulness of Portland cement in removing phosphorus from wastewater has its limitations, as it is necessary to correct the $\mathrm{pH}$ due to the material's strong alkalizing properties [91]. Other tests carried out on pure Portland cement revealed a maximum sorption capacity of $83.00 \mathrm{~g} \mathrm{P} / \mathrm{kg}$, as determined using the Frumkin isotherm model [92].

Brick dust is obtained by mixing ground brick waste with ground red clay at a ratio of 1:10. For this material, Masłon et al. [93] found a maximum sorption capacity (determined according to the Langmuir model) of $0.455 \mathrm{~g} \mathrm{P} / \mathrm{kg}$. Table 20 shows the properties of brick dust compared to powdered expanded clay. Brick dust achieved $54.7 \pm 8.8 \%$ removal of phosphorus compounds from wastewater (initial concentration $3.1 \mathrm{mg} \mathrm{P} / \mathrm{L}$, maximum adsorbent dose equal to $5 \mathrm{~g} / \mathrm{L}$ ) [93].

Table 20. Comparison of powdered ceramsite with brick dust.

\begin{tabular}{|c|c|c|c|c|c|c|c|c|c|}
\hline \multirow{2}{*}{ References } & \multirow{2}{*}{$\begin{array}{l}\text { Description of the } \\
\text { Study }\end{array}$} & \multirow{2}{*}{ Material } & \multicolumn{5}{|c|}{ Composition } & \multirow{2}{*}{$\begin{array}{c}\text { Specific } \\
\text { Surface } \\
\text { Area } \\
{\left[\mathrm{m}^{2} / \mathrm{g}\right]}\end{array}$} & \multirow{2}{*}{$\begin{array}{l}\text { Maximum Sorption } \\
\text { Capacity According } \\
\text { to the Langmuir } \\
\text { Model [g P/kg] }\end{array}$} \\
\hline & & & $\begin{array}{c}\mathrm{Fe}_{2} \mathrm{O}_{3} \\
{[\%]}\end{array}$ & $\begin{array}{c}\mathrm{Al}_{2} \mathrm{O}_{3} \\
{[\%]}\end{array}$ & $\begin{array}{c}\mathrm{SiO}_{2} \\
{[\%]}\end{array}$ & $\begin{array}{c}\mathrm{CaO} \\
{[\%]}\end{array}$ & $\begin{array}{c}\mathrm{MgO} \\
{[\%]}\end{array}$ & & \\
\hline \multirow[t]{2}{*}{ [93] } & $\begin{array}{l}50 \mathrm{~mL} \text { solutions } \\
\text { with initial } \\
\text { concentrations of } \\
2-200 \mathrm{mg} \mathrm{P} / \mathrm{L} \mathrm{+}\end{array}$ & $\begin{array}{l}\text { Powdered } \\
\text { ceramsite }\end{array}$ & 12.91 & 17.56 & 46.28 & 10.62 & 3.58 & 5.18 & 0.59 \\
\hline & $\begin{array}{l}\text { material, shaken } \\
(24 \mathrm{~h})\end{array}$ & brick dust & 7.29 & 18.83 & 62.33 & 2.14 & 2.24 & 4.86 & 0.46 \\
\hline
\end{tabular}

The specific industrial wastes presented in Table 21 have also been studied from the perspective of phosphorus compounds in wastewater. For example, wastes from the treatment of acid mine waters are used in neutralising acidity and removing dissolved Fe. Penn et al. [94] considered two acid mine-drainage treatment residuals with different chemical compositions (ADMR1 and ADMR2), obtaining respective maximum sorption capacities of 40.00 and $29.00 \mathrm{~g} \mathrm{P} / \mathrm{kg}$. This difference reflected the more favourable Ca content in ADMR1.

Table 21. Properties of industrial waste materials.

\begin{tabular}{|c|c|c|c|c|c|c|c|}
\hline Description of the Study & Material & \multicolumn{3}{|c|}{$\begin{array}{c}\text { Composition } \\
\mathrm{CaO}[\%] \mathrm{Fe}_{2} \mathrm{O}_{3}[\%] \mathrm{Al}_{2} \mathrm{O}_{3}[\%]\end{array}$} & \multirow{2}{*}{$\begin{array}{c}\text { Initial } \\
\text { pH } \\
{[-]} \\
8.2\end{array}$} & \multirow{2}{*}{$\begin{array}{c}\text { Final } \\
\text { pH } \\
{[-]} \\
7.21\end{array}$} & \multirow{2}{*}{$\begin{array}{c}\text { Sorption } \\
\text { Capacity } \\
\text { [g P/kg] }\end{array}$} \\
\hline \multirow{6}{*}{$\begin{array}{l}\text { solutions with initial } \\
\text { concentrations } 0-103.23 \mathrm{mg} \\
\mathrm{P} / \mathrm{L}+2 \mathrm{~g} \text { material, contact } \\
\text { time: } 16 \mathrm{~h} \text {, centrifugation: } \\
2000 \mathrm{rpm} \text { for } 15 \mathrm{~min}\end{array}$} & ADMR1 & 30.10 & 8.81 & 0.16 & & & \\
\hline & ADMR2 & 2.26 & 10.28 & 5.55 & 9.1 & 8.30 & 29.0 \\
\hline & WTR & 0.52 & 3.16 & 7.64 & 7.5 & 6.57 & 32.0 \\
\hline & FGD & 19.84 & 0.13 & 0.05 & 7.9 & 4.46 & 14.0 \\
\hline & Red mud & 3.86 & 1.20 & 2.65 & 8.2 & 6.66 & 29.0 \\
\hline & Fly ash & 1.27 & 5.56 & 7.78 & 9.8 & 7.90 & 25.0 \\
\hline
\end{tabular}

Another industrial waste is water treatment sludge (WTR), which contains large amounts of Al due to the use of aluminium sulphate as a coagulating agent. The results for these sludges suggest an adsorption capacity around $32.00 \mathrm{~g} \mathrm{P} / \mathrm{kg}$. The composition in this case is dominated by the $\mathrm{Fe} / \mathrm{Al}$ sorption group, indicating a process based mainly around adsorption [94].

Gypsum is a product of flue-gas desulphurisation, which mainly includes calcium and is thus a mechanism based primarily on the precipitation of calcium phosphates. The phosphorus adsorption capacity in this case was $14.00 \mathrm{~g} \mathrm{P} / \mathrm{kg}$, with a low $\mathrm{pH}$ (of 4.5) found to significantly reduce efficiency [94]. 
Red mud is a by-product that was formed during bauxite leaching in the Bayer trial. This waste raises serious storage-related environmental problems due to its large quantities and alkaline nature. The P-removal capacities were tested for raw red mud versus raw fly ash, as well as their acid-activated and heat-treated forms. Tables 21 and 22 summarise the relevant results. Li et al. [95] shook $20 \mathrm{~mL}$ of $\mathrm{KH}_{2} \mathrm{PO}_{4}$ solution (initial concentration $155 \mathrm{mg} \mathrm{P} / \mathrm{L}$ ) at $180 \mathrm{rpm}$ with $0.1 \mathrm{~g}$ sorbent for $4 \mathrm{~h}$ at $25^{\circ} \mathrm{C}$. In parallel, they also studied the effects of the acidification or calcination of the raw materials on phosphate sorption. The results indicated that the materials calcined at $700{ }^{\circ} \mathrm{C}$ offered the greatest efficiency. With acid activation, the optimal version involved $0.25 \mathrm{~mol} / \mathrm{L} \mathrm{HCl}$. Activated red mud in the two variants achieved a P-removal efficiency of $99.0 \%$, while the raw-form's efficiency was $47.8 \%$. Fly ash achieved a $45.2 \%$ removal efficiency following acid activation and $52.9 \%$ after undergoing heat treatment. The level for the raw form of fly ash was $16.1 \%$. The Freundlich and Langmuir models were used to simulate the sorption equilibrium, with a better correlation in the latter context. Red sludge activated by heat treatment at $700{ }^{\circ} \mathrm{C}$ proved the most efficient at removing phosphorus, presenting the highest sorption capacity [95]. Using the same material, Penn et al. [94] found sorption capacities of 25.00 and $29.00 \mathrm{~g} \mathrm{P} / \mathrm{kg}$ for red mud and fly ash, respectively (see Table 22).

Table 22. Results for red mud and fly ash.

\begin{tabular}{|c|c|c|c|c|c|c|c|c|c|}
\hline \multirow{2}{*}{\multicolumn{2}{|c|}{ Material }} & \multicolumn{5}{|c|}{ Composition } & \multirow{2}{*}{$\begin{array}{c}\text { Specific } \\
\text { Surface } \\
\text { Area } \\
{\left[\mathrm{m}^{2} / \mathrm{g}\right]}\end{array}$} & \multirow{2}{*}{$\begin{array}{c}\text { Phosphorus } \\
\text { Removal } \\
\text { Efficiency } \\
{[\%]}\end{array}$} & \multirow{2}{*}{$\begin{array}{l}\text { Maximum Sorption } \\
\text { Capacity According } \\
\text { to the Langmuir } \\
\text { Model [g P/kg] }\end{array}$} \\
\hline & & $\begin{array}{c}\mathrm{Fe}_{2} \mathrm{O}_{3} \\
{[\%]}\end{array}$ & $\begin{array}{c}\mathrm{Al}_{2} \mathrm{O}_{3} \\
{[\%]}\end{array}$ & $\begin{array}{c}\mathrm{SiO}_{2} \\
{[\%]}\end{array}$ & $\begin{array}{c}\mathrm{CaO} \\
{[\%]}\end{array}$ & $\begin{array}{c}\mathrm{MgO} \\
{[\%]}\end{array}$ & & & \\
\hline \multirow{3}{*}{$\begin{array}{l}\text { Red } \\
\text { mud }\end{array}$} & raw & 12.76 & 6.93 & 19.14 & 46.02 & 1.15 & 14.09 & 47.8 & 113.87 \\
\hline & $\begin{array}{c}\text { activated } \\
0.25 \mathrm{HCl}\end{array}$ & 14.84 & 7.20 & 20.34 & 45.16 & 1.42 & 19.35 & 99.0 & 161.61 \\
\hline & $\begin{array}{l}\text { calcinated } \\
\text { at } 700{ }^{\circ} \mathrm{C}\end{array}$ & 13.05 & 8.06 & 22.45 & 45.23 & 1.14 & 9.69 & 99.0 & 345.50 \\
\hline \multirow{3}{*}{ Fly ash } & raw & 7.35 & 25.36 & 56.38 & 2.72 & 1.45 & 14.55 & 16.1 & 63.22 \\
\hline & $\begin{array}{c}\text { activated } \\
0.25 \mathrm{HCl}\end{array}$ & 7.02 & 27.10 & 56.75 & 2.13 & 1.85 & 18.70 & 45.2 & 78.44 \\
\hline & $\begin{array}{c}\text { calcinated } \\
\text { at } 700{ }^{\circ} \mathrm{C}\end{array}$ & 6.09 & 28.47 & 57.2 & 2.14 & 1.57 & 12.20 & 52.9 & 58.92 \\
\hline
\end{tabular}

Research has also sought to determine the capacity to remove phosphorus by ash from the clinker, as well as in the iron oxide tailings from copper and nickel mines [96]. The results are shown in Table 23. Iron oxide tailings were found to have a greater capacity to remove $\mathrm{P}$ (at $1.29 \mathrm{~g} \mathrm{P} / \mathrm{kg}$ ) compared to the clinker ash $(0.29 \mathrm{~g} \mathrm{P} / \mathrm{kg})$. However, the latter has more suitable physical properties for the adsorption process. Testing involved $100 \mathrm{~mL}$ of domestic sewage, with various doses of adsorbent added prior to $24 \mathrm{~h}$ of shaking on an orbital shaker at $120 \mathrm{rpm}$ at room temperature. Data were set against linear forms of the Langmuir and Freundlich equations, with the former offering the best fit for the determination of sorption capacity. Analysis also showed that iron oxide tailings have a higher regenerative potential than clinker ash, suggesting that they are the better adsorbent [96].

Table 23. Results of research on iron oxide tailings and clinker ash.

\begin{tabular}{|c|c|c|c|c|c|c|c|c|c|c|}
\hline \multirow[b]{2}{*}{ Material } & \multicolumn{5}{|c|}{ Composition } & \multicolumn{4}{|c|}{ Physical Parameters } & \multirow{2}{*}{$\begin{array}{c}\text { Maximum Sorption } \\
\text { Capacity According to } \\
\text { the Langmuir Model } \\
{[\mathrm{g} \mathrm{P} / \mathrm{kg}]}\end{array}$} \\
\hline & $\begin{array}{c}\mathrm{Fe}_{2} \mathrm{O}_{3} \\
{[\%]}\end{array}$ & $\begin{array}{c}\mathrm{Al}_{2} \mathrm{O}_{3} \\
{[\%]}\end{array}$ & $\begin{array}{c}\mathrm{SiO}_{2} \\
{[\%]}\end{array}$ & $\begin{array}{l}\mathrm{CaO} \\
{[\%]}\end{array}$ & $\underset{[\%]}{\mathrm{MgO}}$ & $\begin{array}{c}\text { Bulk } \\
\text { Density } \\
{\left[\mathrm{g} / \mathrm{m}^{3}\right]}\end{array}$ & $\begin{array}{c}\text { Particle } \\
\text { Density } \\
{\left[\mathrm{g} / \mathrm{m}^{3}\right]}\end{array}$ & $\begin{array}{c}\text { Porosity } \\
{[\%]}\end{array}$ & $\begin{array}{c}\text { Hydraulic } \\
\text { Conductivity } \\
{[\mathrm{m} / \mathrm{s}]}\end{array}$ & \\
\hline $\begin{array}{l}\text { Iron oxide } \\
\text { tailings }\end{array}$ & 25.10 & 5.40 & 18.50 & 4.20 & 3.00 & 1.00 & 2.00 & 48.50 & 0.00011 & 1.29 \\
\hline $\begin{array}{l}\text { Clinker } \\
\text { ash }\end{array}$ & 5.30 & 11.70 & 18.60 & 6.00 & 0.40 & 1.30 & 2.90 & 56.70 & 2.60 & 0.29 \\
\hline
\end{tabular}

Some wastes from the agri-food industry show phosphorus sorption properties. For example, Arachis hypogaea husks contain polysaccharides. Unmodified husks have a negative charge in the solution but possess a positive charge after ammonization [97]. The sorption capacity was determined by adding sorbents at a dose of $5 \mathrm{~g} / \mathrm{L}$ to $200 \mathrm{~mL}$ of solutions with concentrations from 0.1 to $5 \mathrm{mg}$ $\mathrm{P} / \mathrm{L}$, which were shaken for $1 \mathrm{~h}$. The Freundlich, Langmuir, and double Langmuir models were used 
to describe the results. The Langmuir model showed the best fit, based on which the maximum sorption capacity was determined: $0.01 \mathrm{~g} \mathrm{P} / \mathrm{kg}$ for unmodified husks and $0.10 \mathrm{~g} \mathrm{P} / \mathrm{kg}$ for modified husks. Therefore, the amino groups introduced during modification are the main factor that causes phosphorus sorption. Table 24 shows the optimal $\mathrm{pH}$ values of phosphorus removal for husks and solution reactions that can be obtained after this process. The neutralization ability of husks is crucial when they are used in wastewater treatment plants [97]. Studies on the sorption capacity of phosphorus by chitin and chitosan flakes have also confirmed that the adsorption capacity depends on the amount of amino groups [98]. According to Table 24, the maximum sorption capacity determined according to the Langmuir model was $6.64 \mathrm{~g} \mathrm{P} / \mathrm{kg}$ for chitosan and $2.09 \mathrm{~g} \mathrm{P} / \mathrm{kg}$ for chitin. The better efficiency of chitosan in removing phosphorus is because chitosan has more amino groups on its surface than chitin does. In addition, the optimal $\mathrm{pH}$ for phosphorus removal by chitin is 3.0, with a final solution $\mathrm{pH}$ of 3.3. For chitosan, the optimum $\mathrm{pH}$ for the process is 4.0. However, due to the ability to neutralize the solution, a final $\mathrm{pH}$ of 6.75 can be obtained; thus, $\mathrm{pH}$ correction is not required after the adsorption process [98].

Table 24. Waste from the agri-food industry.

\begin{tabular}{cccccc}
\hline Material & $\begin{array}{c}\text { Maximum Sorption } \\
\text { Capacity According to the } \\
\text { Langmuir Model [g P/kg] }\end{array}$ & $\begin{array}{c}\text { Initial } \mathbf{~ p H} \\
{[-]}\end{array}$ & $\begin{array}{c}\text { Final PH } \\
{[-]}\end{array}$ & $\begin{array}{c}\text { Optimal } \\
\mathbf{p H}[-]\end{array}$ & $\begin{array}{c}\text { Final } \mathbf{~ p H} \text { of the } \\
\text { Solution at } \\
\text { Optimal } \mathbf{~ p H ~ [ - ] ~}\end{array}$ \\
\hline $\begin{array}{c}\text { Arachis hypogaea } \\
\text { husks, unmodified }\end{array}$ & 0.01 & $5.00-8.00$ & $6.94-7.54$ & 8.00 & 7.54 \\
\hline $\begin{array}{c}\text { Arachis hypogaea } \\
\text { husks, modified }\end{array}$ & 0.10 & $5.00-8.00$ & $6.64-7.85$ & 5.00 & 6.64 \\
\hline Chitin & 2.09 & $5.00-7.00$ & $6.74-7.10$ & 3.00 & 3.33 \\
\hline Chitosan & 6.64 & $4.00-8.00$ & $6.75-7.86$ & 4.00 & 6.75 \\
\hline
\end{tabular}

\section{Man-Made Materials}

Man-made materials are materials with precisely fixed chemical compositions that have been commercialised and are sold in bulk.

Polonite ${ }^{\circledR}$ is sedimentary opoka heat-treated at $900{ }^{\circ} \mathrm{C}$ to convert $\mathrm{CaCO}_{3}$ into the more-reactive CaO. Polonite ${ }^{\circledR}$ usually has a 2.0-6.0 mm fraction. Kaczmarczyk et al. [99] provide an estimated phosphorus adsorption capacity of $40.90 \mathrm{~g} \mathrm{P} / \mathrm{kg}$. They also reported on column experiments, finding phosphorus-removal efficiencies of $52.8 \%$ for wastewater (initial concentration $10.69 \mathrm{mg} \mathrm{P} / \mathrm{L}$ ) and $72.4 \%$ for synthetic solutions (initial concentration $4.41 \mathrm{mg} \mathrm{P} / \mathrm{L}$ ). Other, long-term experiments confirmed phosphorus removal efficiency by Polonite ${ }^{\circledR}$ to be around $97.0 \%$ for synthetic solutions and $92.0 \%$ for wastewater. This indicates that the other impurities present in wastewater have an impact on the adsorption process [100].

Leca $^{\circledR}$ is a lightweight aggregate obtained from expanded clay. Kaczmarczyk et al. [99] obtained an estimate for phosphorus adsorption capacity equal to $5.10 \mathrm{~g} \mathrm{P} / \mathrm{kg}$. The removal efficiency noted in their column experiments was 31.7\% for wastewater (initial concentration $10.69 \mathrm{mg} \mathrm{P} / \mathrm{L}$ ) and $28.3 \%$ for synthetic solutions (initial concentration $4.41 \mathrm{mg} \mathrm{P} / \mathrm{L}$ ) [99]. The powdered expanded clay fraction was tested by Masłon et al. [93,101], with the result providing a maximum sorption capacity of $0.593 \mathrm{~g} \mathrm{P} / \mathrm{kg}$ (Table 20). When the product was used on wastewater (initial concentration $3.1 \mathrm{mg} \mathrm{P} / \mathrm{L}$ ), a phosphorus removal efficiency of $80.7 \pm 8.7 \%$ was obtained with a maximum adsorbent dose of $5 \mathrm{~g} / \mathrm{L}$. A slight increase in $\mathrm{pH}$ from 7.56 to 7.69 was also noted. Expanded clay also has the ability to improve the sedimentation of activated sludge and biogranulation in a granular sequencing batch reactor [102-104].

Lightweight aggregates (LWAs) can be clay or shale [105]; the production process involves clay aggregates passing through a rotary kiln at $1200^{\circ} \mathrm{C}$. Tests on this material differ significantly from each other in terms of their results, as both origin and chemical composition significantly affect the amount of sorption. The highest level of sorption observed (12.00 g P/kg) was given by Jenssen et al. [106]. 
Compared to the analysis carried out by Zhu et al. [105], where the sorption capacity was $3.47 \mathrm{~g} \mathrm{P} / \mathrm{kg}$, the better efficiency of Jenssen et al. likely resulted from a higher content of dolomite [106].

$\operatorname{Rockfos}^{\circledR}$ is a waste material obtained when opoka is heat-treated above $700{ }^{\circ} \mathrm{C}$. Kasprzyk et al. [107] gave the high maximum phosphorus sorption capacity for this material (equal to $256.40 \mathrm{~g} \mathrm{P} / \mathrm{kg}$ ).

Pollytag ${ }^{\circledR}$ is an aggregate made from fly ash via granulation and sintering at a temperature of $1000-1350^{\circ} \mathrm{C}$. An analysis by Bus et al. [108] showed that, at higher initial concentrations, Pollytag ${ }^{\circledR}$ is characterised by a higher efficiency of phosphorus removal. At concentrations of $1-3 \mathrm{mg} \mathrm{P} / \mathrm{L}$, the efficiency of phosphorus removal is $1.0-2.5 \%$. However, at an initial concentration of $10 \mathrm{mg} P / \mathrm{L}$, the efficiency achieved is $34.0 \%$. Pollytag ${ }^{\circledR}$ is thus a good reactive material for removing phosphorus from wastewater in cases where concentrations of phosphorus are in the $8-19 \mathrm{mg} \mathrm{P} / \mathrm{L}$ range. The sorption capacity of this material, determined according to the Langmuir model, was $32.24 \mathrm{~g} \mathrm{P} / \mathrm{kg}$ [108].

Filtralite $^{\circledR}$ is a new-generation LWA made in Norway from natural ilitic mineral clay with natural additives. Adam et al. [64] showed how, at an initial concentration of $480 \mathrm{mg} \mathrm{P} / \mathrm{L}$, the adsorption capacity is only $2.50 \mathrm{~g} \mathrm{P} / \mathrm{kg}$. However, compared with other materials, Filtralite ${ }^{\circledR}$ was shown to be a more effective remover of phosphorus when initial concentrations were lower, which is an important finding from the perspective of wastewater treatment. Column experiments showed a $>90.0 \%$ sorption capacity for the tested material in wastewater compared to $54.0 \%$ for the synthetic solutions (perhaps due to the presence of other ions and the formation of a biofilm) [64].

Filtra $P$ is produced by heating materials such as limestone, gypsum, and iron oxides. Analysis of this material by Jourak et al. [109] showed that, where initial concentrations were in the range of 3-100 $\mathrm{mg} / \mathrm{L}$, phosphorus in the solution was removed completely and bound quickly to the material. The maximum adsorption capacity was $4.30 \mathrm{~g} \mathrm{P} / \mathrm{kg}$ (with an initial concentration of $300 \mathrm{mg} \mathrm{P} / \mathrm{L}$ ).

Table 25 compares the properties of the best known examples of man-made materials for the removal of phosphorus from wastewater by sorption and precipitation.

Table 25. Man-made materials.

\begin{tabular}{|c|c|c|c|c|c|}
\hline References & Material & Description of the Study & $\begin{array}{c}\mathrm{pH} \\
{[-]}\end{array}$ & $\begin{array}{l}\text { Porosity } \\
{[\%]}\end{array}$ & $\begin{array}{c}\text { Sorption } \\
\text { Capacity } \\
{[\mathrm{g} \mathrm{P} / \mathrm{kg}]}\end{array}$ \\
\hline [92] & Polonite ${ }^{\circledR}$ & solutions with initial concentrations of & 12.0 & 38.00 & $40.90^{(\mathrm{L})}$ \\
\hline [92] & Leca ${ }^{\circledR}$ & $100-1100 \mathrm{mg} P / \mathrm{L}+1 \mathrm{~g}$ material, shaken for $24 \mathrm{~h}$ & 7.5 & 48.00 & $5.10^{(\mathrm{L})}$ \\
\hline [105] & LWA & $\begin{array}{l}\text { solutions with initial concentrations of } 0-320 \\
\mathrm{mg} \mathrm{P} / \mathrm{L}+8 \mathrm{~g} \text { material, shaken for } 24 \mathrm{~h}\end{array}$ & - & - & 3.47 \\
\hline [106] & LWA & $\begin{array}{l}\text { solutions with initial concentrations of } 320-480 \\
\mathrm{mg} \mathrm{P} / \mathrm{L}+3 \mathrm{~g} \text { material, shaken for } 24 \mathrm{~h}\end{array}$ & - & - & 12.00 \\
\hline [107] & $\operatorname{Rockfos}^{\circledR}{ }^{(*)}$ & $\begin{array}{l}\text { solutions with initial concentrations of } 5-100 \\
\mathrm{mg} \mathrm{P} / \mathrm{L}+10 \mathrm{~g} \text { material shaken for } 1 \mathrm{~h}\end{array}$ & $11.0-12.0$ & $>50.00$ & $256.40^{(\mathrm{L})}$ \\
\hline [108] & Pollytag $^{\circledR}{ }^{(* *)}$ & $\begin{array}{l}\text { solutions with initial concentrations of } 1.28-949 \\
\mathrm{mg} \mathrm{P} / \mathrm{L}+1 \mathrm{~g} \text { material, shaken for } 15 \mathrm{~min}\end{array}$ & 7.4 & 62.00 & 32.24 \\
\hline [64] & Filtralite $^{\circledR}$ & $\begin{array}{l}\text { do solutions with initial concentrations of } \\
0-480 \mathrm{mg} \mathrm{P} / \mathrm{L}+3 \mathrm{~g} \text { material, shaken for } 24 \mathrm{~h}\end{array}$ & 10.7 & 68.00 & $2.50^{(\mathrm{L})}$ \\
\hline [110] & Filtra $P^{(* * *)}$ & $\begin{array}{l}\text { do solutions with initial concentrations of } \\
3-1000 \mathrm{mg} \mathrm{P} / \mathrm{L}+25 \mathrm{~g} \text { material, shaken for } 48 \mathrm{~h}\end{array}$ & - & - & 4.30 \\
\hline
\end{tabular}

\section{Summary}

The present analysis of sorption properties included natural, waste, synthesized, and commercial materials, as well as modified versions thereof. A careful review of previous research can determine the impact that the chemical and physical compositions of these materials, as well as their process conditions, have on the ability to bind phosphorus. As the experimental conditions applied were variable, each material was analysed separately to determine each factor's potential effects on sorption capacity.

The literature shows that the search for effective reactive materials is always focused on natural materials. Sorption tests carried out on these materials determine whether industrial waste containing a given natural substrate could, in the future, be used to remove P from wastewater and whether 
synthetic modifications of the materials make sense. Analysis of the properties of the natural materials also determines the effective substrates for the modification processes by which the sorption properties of other materials could be improved.

Natural materials are characterised by their lower removal efficiency (sorption capacity) of phosphorus compounds from various solutions $(52.02 \mathrm{~g} \mathrm{P} / \mathrm{kg}$ for dolomite, $10.70 \mathrm{~g} \mathrm{P} / \mathrm{kg}$ for diatomite, $26.04 \mathrm{~g} \mathrm{P} / \mathrm{kg}$ for sand from shells, and $19.60 \mathrm{~g} \mathrm{P} / \mathrm{kg}$ for opoka) than their modifications using thermal or chemical treatments. Thus, for example, the sorption capacity of roasted opoka reaches a level of $181.82 \mathrm{~g} \mathrm{P} / \mathrm{kg}$. However, raw waste materials, depending on their location, prove highly efficient at removing $\mathrm{P}$ (with red mud at $345.50 \mathrm{~g} \mathrm{P} / \mathrm{kg}$, wastes from the treatment of acid mine water ar $40.00 \mathrm{~g} \mathrm{P} / \mathrm{kg}$, fly ash at $78.44 \mathrm{~g} \mathrm{P} / \mathrm{kg}$, blast-furnace slag at $75.70 \mathrm{~g} \mathrm{P} / \mathrm{kg}$, and autoclaved aerated concrete at $12.25 \mathrm{~g} \mathrm{P} / \mathrm{kg}$ ). Synthesized materials, due to their ability to possess the necessary properties, are characterized by a high sorption capacity (e.g., nano-valent iron barriers (nZVI), $54.34 \mathrm{~g} \mathrm{P} / \mathrm{kg}$ ).

Other materials modify natural and raw waste materials in combination, with an example being biochar + dolomite, which can achieve $29.18 \mathrm{~g} \mathrm{P} / \mathrm{kg}$ sorption. Materials can also be improved by applying nanoparticles of appropriate compounds to their surfaces. Biochar coated with $\mathrm{MgO}$ nanoparticles achieved a sorption-capacity value of $60.95 \mathrm{~g} \mathrm{P} / \mathrm{kg}$. Commercialised man-made materials obviously achieve a high efficiency of phosphorus removal, as does Polonite ${ }^{\circledR}$, with a $40.90 \mathrm{~g} \mathrm{P} / \mathrm{kg}$ sorption capacity and $\operatorname{Rockfos}^{\circledR}$, with a capacity of $256.40 \mathrm{~g} \mathrm{P} / \mathrm{kg}$.

Since the adsorption process is not yet fully understood, and there are many methods for testing potential sorbents, it remains very difficult to engage in meaningful comparisons between different materials. Furthermore, adsorption is a process that is sensitive to any change in conditions. Any analysis needs to account for the circumstances in which a process occurs and for the impact of many different factors. When a reactive material is chosen, the pattern followed must provide a rational determination of each given substrate's properties. The physical parameters and chemical composition should be determined first, before the adsorbent dose and adsorbate concentration are selected in line with the potential application. The next step involves static tests that are conducted to determine the sorption capacity and kinetics of the adsorption process, followed by column and field tests performed to confirm the static tests [84].

The analysis provided here shows the higher sorption capacities of materials whose initial phosphorus concentrations are greater. The exception to this rule is shale, which showed an opposite trend [23,24]. The results in the literature further suggest a higher process efficiency with a higher dose of the adsorbent.

However, the selection of reactive materials for use in the treatment of wastewater necessitates consideration of the P-removal efficiency, as the concentrations of P should correspond to those present in real wastewater. The $\mathrm{pH}$ for the process must also be adequate and adjusted as necessary during the process line of a given wastewater treatment plant.

The economic aspects of using a material in the technological process of a sewage treatment plant must also be considered. The present analysis shows that modified materials offer the best efficiency. Notably, all modifications or improvements (through calcination, particle application, or the addition of other reagents) entail costs that affect the final price of the product. When planning the modernization or construction of a wastewater treatment plant, the market value of the material should be estimated, and the possibility of its future changes should be assessed. This is done to determine the cost-effectiveness of using the technology with a given material. In addition to modification costs, the price of the material is also influenced by the size of the available resources and the cost of transport.

Due to the wide variety of research methods used, as well as the different chemical compositions, it is difficult to determine a perfect comparison of materials based on their efficiency in removing phosphorus from wastewater. Such confirmation may also come from differences in the results of tests using the same natural materials, whose chemical compositions are slightly different due to the places of their extraction. Therefore, each material should be approached individually, with a proper selection of research conditions in line with the potential application. 


\subsection{The Influence of a Material's Chemical Composition, $p H$ and Physical Properties on Phosphorus Sorption}

For removing phosphorus from wastewater or other water, any potential reactive material should have a chemical composition rich in compounds that can retain $\mathrm{P}$-i.e., $\mathrm{Ca}, \mathrm{Mg}$, $\mathrm{Fe}$, and $\mathrm{Al}$. Considering the method by which these compounds bind phosphorus, a distinction must be drawn between materials with dominant sorption groups (either $\mathrm{Al} / \mathrm{Fe}$ or $\mathrm{Ca} / \mathrm{Mg}$ ). The properties differ here, with $\mathrm{Ca}$ playing the key role within the $\mathrm{Ca} / \mathrm{Mg}$ sorption group, which precipitates $\mathrm{P}$ in the form of sparingly soluble compounds. The research cited here shows that materials with $\mathrm{Ca}$ in the form of $\mathrm{CaCO}_{3}$ have a lower phosphorus sorption capacity than substrates with $\mathrm{CaO}$ or $\mathrm{Ca}(\mathrm{OH})_{2}$ [47]. However, thermal treatment raises the sorption capacity, as a high-temperature conversion of calcium carbonate to calcium oxide and carbon dioxide occurs. This is true of opoka, whose sorption capacity after calcination increases by ca. sixfold [41]. A similar factor applies to marine materials like oyster shells, mussels, and corals, whose effectiveness in removing phosphorus increases from six- to eightfold via pyrolysis [60]. Heat-treated marble likewise possesses altered Ca content (risen from 32.9\% to $48.2 \%$ ), with phosphorus binding shown to increase from 103.20 to $181.20 \mathrm{~g} \mathrm{P} / \mathrm{kg}$ [37]. For red mud with $\mathrm{CaO}$ equal to $46.0 \%$, the sorption capacity increased threefold following calcination (to $345.50 \mathrm{~g} \mathrm{P} / \mathrm{kg}$ ). This was, in fact, the highest value noted for any of the materials presented [95].

Notably, the use of materials with high Ca content in phosphorus removal increases the solution $\mathrm{pH}$ from 8.0 to 13.0. Where practical wastewater treatment is involved, this factor will necessitate $\mathrm{pH}$ correction via additional processes like dilution or aeration. Another problem with filters using reactive materials containing dominant $\mathrm{Ca}$ content involves plugging via cement formation as $\mathrm{CaCO}_{3}$ crystallises. This problem can be solved by removing $\mathrm{CO}_{2}$ or by using carriers over $5 \mathrm{~mm}$ in size [48].

The $\mathrm{Al} / \mathrm{Fe}$ sorption group participates in a phosphorus-binding process in which there is an exchange of the ligands of hydrolysed complexes (formed due to the presence of aluminium or iron ions). The sorption capacity of materials containing this group increases over the $\mathrm{pH}$ range from neutral to acidic [13], which was confirmed, for example, for aluminium hydroxide (whose maximum adsorption occurs at $\mathrm{pH}$ values between 4 and 6). Vohla et al. [48] state that any process involving sands or gravels at $\mathrm{pH}$ values above 6 combines the adsorption of iron and aluminium on oxides, while the process at lower $\mathrm{pH}$ values entails the precipitation of iron and gallium phosphates (strengite, variscite). Among the presented materials containing dominant $\mathrm{Al} / \mathrm{Fe}$ groups, products based on fly ash offer the greatest sorption capacity. Pollytag ${ }^{\circledR}$ provided a phosphorus binding capacity of $34.00 \mathrm{~g} \mathrm{P} / \mathrm{kg}$, while fly ash activated with $0.25 \mathrm{M} \mathrm{HCl}$ offered a value of $78.44 \mathrm{~g} \mathrm{P} / \mathrm{kg}$.

While the most important physical properties of materials are porosity and specific surface area, the material's use as a filtration medium determines all the parameters that can affect functioning. The assumption that the greater SSA is, the better the contact between the adsorbent and the pollutant will be was confirmed for most of the materials presented. Only for akadama clay did a raw material with a greater SSA (equal to $117.67 \mathrm{~m}^{2} / \mathrm{g}$ ) present a lower sorption capacity $(5.88 \mathrm{~g} \mathrm{P} / \mathrm{kg}$ ) than a material modified with SSA (down to $75.27 \mathrm{~m}^{2} / \mathrm{g}$, for a sorption capacity of $9.19 \mathrm{~g} \mathrm{P} / \mathrm{kg}$ ).

Acid modification was shown to increase the pore volume and thus the active sites, thereby increasing the sorption capacity [19]. This confirms that each material must be considered individually.

\subsection{Possible Use of Reactive Materials in Fertiliser Production}

Reactive materials with adsorbed phosphorus can be reused in agricultural production-for example, to increase the capacity of soil to retain water or to ensure a supply of plant nutrients. Equally, phosphorus compounds removed from wastewater through selective sorption in the solid phase can be directly used as fertilisers or soil conditioners. A second option involves recovering $\mathrm{P}$ from reactive materials via chemical precipitation with salts of $\mathrm{Mg}$ or $\mathrm{Ca}$, thereby producing a high-purity fertiliser [111]. P-enriched materials can also be used in agriculture when the form is plant-available. The presence of toxic compounds and pathogens limits any potential use in agriculture-e.g., due to high levels of leaching metals and metalloids. In addition, materials should 
have high permeability to avoid clogging. Ca-related forms of phosphorus are more plant-available than their $\mathrm{Al}$ or Fe-related forms.

Generally, however, any broader view taken as new reactive materials are sought should entertain the possibility of ultimate reuse in agriculture, which complies with the assumptions of the circular economy.

\section{Conclusions}

This paper has reviewed the materials able to bind phosphorus via sorption and/or precipitation.

Due to the variety of materials and their properties, it is not possible to draw uniform conclusions for all tested materials. Among the natural materials, calcined opoka achieved the highest sorption capacity of $181.20 \mathrm{~g} \mathrm{P} / \mathrm{kg}$. Among the waste materials, red calcined sludge proved the most efficient at sorbing phosphorus, with $345.02 \mathrm{~g} \mathrm{P} / \mathrm{kg}$. Within the group of commercial materials, Rockfos ${ }^{\circledR}$ demonstrated the highest sorption capacity (with a reported value of $256.40 \mathrm{~g} \mathrm{P} / \mathrm{kg}$ ). Among the synthesized materials, nano-valent iron (nZVI) barriers offered the best sorption capacity at $54.34 \mathrm{~g}$ $\mathrm{P} / \mathrm{kg}$. Natural materials have been the most commonly studied, as these materials represent a starting point for the waste materials to be tested, as well as the modifications of materials. Indications for further research in the field are also supplied in this paper. As reactive materials are sought, the matter of sorption capacity vis-à-vis phosphorus should be supplemented by a consideration of physical properties more generally (and the potential for contamination). Cost and availability are also of obvious importance given the need for economically viable materials.

Considering the ongoing demand for phosphorus compounds and the lack of synthetic substitutes, new materials should be sought in the perspective of using their form with adsorbed phosphorus in the production of fertilizers. In this case, materials with a predominant $\mathrm{Ca} / \mathrm{Mg}$ sorption group are more useful because of their easier accessibility for plants. Further research should also assess materials for their sorption of heavy metals and for the general presence of toxic compounds and pathogens likely to limit any use in agriculture.

Author Contributions: Conceptualization, S.G., A.M. and J.C.; writing-original draft preparation, S.G.; writing-review and editing, formal analysis, A.M. and J.C.; validation, A.M., J.C. and P.K.; supervision, A.M. and P.K.; project administration, A.M. All authors have read and agreed to the published version of the manuscript.

Funding: This research received no external funding.

Conflicts of Interest: The authors declare no conflict of interest.

\section{References}

1. Wiackowski, S. General Ecology, 1st ed.; BRANTA: Bydgoszcz, Poland, 1998; pp. 125-147.

2. Schlesinger, W.H.; Bernhardt, E. Biogeochemistry: An Analysis of Global Change, 3rd ed.; Academic Press: Waltham, MA, USA, 2013; pp. 360-418.

3. Cieslik, B.; Konieczka, P. A review of phosphorus recovery methods at various steps of wastewater treatment and sewage sludge management. The concept of "no solid waste generation" and analytical methods. J. Clean Prod. 2017, 142, 1728-1740. [CrossRef]

4. Sorensen, B.L.; Dall, O.L.; Habib, K. Environmental and resource implications of phosphorus recovery from waste activated sludge. Waste Manag. 2015, 45, 391-399. [CrossRef]

5. Schindler, D.W.; Carpenter, S.R.; Chapra, S.C.; Hecky, R.E.; Orihel, D.M. Reducing Phosphorus to Curb Lake Eutrophication is a Success. Environ. Sci. Technol. 2016, 50, 8923-8929. [CrossRef] [PubMed]

6. Chen, M.P.; Graedel, T.E. A half-century of global phosphorus flows, stocks, production, consumption, recycling, and environmental impacts. Glob. Environ. Chang.-Hum. Policy Dimens. 2016, 36, 139-152. [CrossRef]

7. Roy, E.D. Phosphorus recovery and recycling with ecological engineering: A review. Ecol. Eng. 2017, 98, 213-227. [CrossRef] 
8. Regulation of the Minister of Maritime Economy and Inland Navigation of 12 July 2019 on substances particularly harmful to the aquatic environment and conditions to be met when introducing sewage into waters or into the ground, as well as when discharging rainwater or snowmelt into waters or into water equipment. Dz. U. (J. Laws.) 2019, 1311. (In Polish)

9. Siwek, H.; Bartkowiak, A.; Wlodarczyk, M. Adsorption of Phosphates from Aqueous Solutions on Alginate/Goethite Hydrogel Composite. Water 2019, 11, 633. [CrossRef]

10. Bartczak, P. Assessment of the Sorption Capacity of Natural Materials in Removing Selected Inorganic and Organic Compounds, Taking into Account Water Applications; Politechnika Poznańska: Poznań, Poland, 2017.

11. Dabrowski, A. Adsorption-from theory to practice. Adv. Colloid Interface Sci. 2001, 93, 135-224. [CrossRef]

12. Weber, T.W.; Chakkravorti, R.K. Pore and Solid Diffusion Models for Fixed-Bed Adsorbers. AIChE J. 1974, 20, 228-238. [CrossRef]

13. Wu, D.Y.; Zhang, B.H.; Li, C.J.; Zhang, Z.J.; Kong, H.N. Simultaneous removal of ammonium and phosphate by zeolite synthesized from fly ash as influenced by salt treatment. J. Colloid Interface Sci. 2006, 304, 300-306. [CrossRef]

14. Drizo, A.; Frost, C.A.; Grace, J.; Smith, K.A. Physico-chemical screening of phosphate-removing substrates for use in constructed wetland systems. Water Res. 1999, 33, 3595-3602. [CrossRef]

15. Altundogan, H.S.; Tumen, F. Removal of phosphates from aqueous solutions by using bauxite. I: Effect of $\mathrm{pH}$ on the adsorption of various phosphates. J. Chem. Technol. Biotechnol. 2002, 77, 77-85. [CrossRef]

16. Altundogan, H.S.; Tumen, F. Removal of phosphates from aqueous solutions by using bauxite II: The activation study. J. Chem. Technol. Biotechnol. 2003, 78, 824-833. [CrossRef]

17. Xiong, W.H.; Peng, J. Development and characterization of ferrihydrite-modified diatomite as a phosphorus adsorbent. Water Res. 2008, 42, 4869-4877. [CrossRef] [PubMed]

18. Xie, F.Z.; Da, C.N.; Zhang, F.J.; Zhang, J.; Han, X.; Ge, Y.J.; Li, G.L. Phosphorus Removal from Eutrophic Waters with a Novel Lanthanum-Modified Diatomite. Asian J. Chem. 2013, 25, 5759-5761. [CrossRef]

19. Wang, Y.; He, H.; Zhang, N.; Shimizu, K.; Lei, Z.F.; Zhang, Z.Y. Efficient capture of phosphate from aqueous solution using acid activated akadama clay and mechanisms analysis. Water Sci. Technol. 2018, 78, 1603-1614. [CrossRef]

20. Glocheux, Y.; Pasarin, M.M.; Albadarin, A.B.; Mangwandi, C.; Chazarenc, F.; Walker, G.M. Phosphorus adsorption onto an industrial acidified laterite by-product: Equilibrium and thermodynamic investigation. Asia-Pac. J. Chem. Eng. 2014, 9, 929-940. [CrossRef]

21. Zhang, L.A.; Hong, S.; He, J.; Gan, F.X.; Ho, Y.S. Adsorption characteristic studies of phosphorus onto laterite. Desalin. Water Treat. 2011, 25, 98-105. [CrossRef]

22. Wood, R.B.; McAtamney, C.F. Constructed wetlands for waste water treatment: The use of laterite in the bed medium in phosphorus and heavy metal removal. Hydrobiologia 1996, 340, 323-331. [CrossRef]

23. Cyrus, J.S.; Reddy, G.B. Sorption and Desorption of Nitrogen and Phosphorus by Zeolite and Shale. In Proceedings of the 2007 National Conference on Environmental Science and Technology; Nzewi, E., Reddy, G., Luster-Teasley, S., Kabadi, V., Chang, S.-Y., Uzochukwu, G., Eds.; Springer Science+Buisness Media, LLC: New York, NY, USA, 2009; pp. 353-364. [CrossRef]

24. Cyrus, J.S.; Reddy, G.B. Sorption and desorption of phosphorus by shale: Batch and column studies. Water Sci. Technol. 2010, 61, 599-606. [CrossRef]

25. Kpannieu, D.E.; Ruby, C.; Coulibaly, L.; Abdelmoula, M.; Mallet, M. Removal of phosphate by ivory coast shale in a homogeneous reactor and under hydrodynamic conditions: Influence of soluble species. Clays Clay Miner. 2018, 66, 500-514. [CrossRef]

26. Sakadevan, K.; Bavor, H.J. Phosphate adsorption characteristics of soils, slags and zeolite to be used as substrates in constructed wetland systems. Water Res. 1998, 32, 393-399. [CrossRef]

27. Srinivasan, R.; Hoffman, D.; Wolfe, J. ENVR 39-Evaluating above-ground permeable reactive barrier materials: Sorption efficiencies for orthophosphate-P and ammonia-N onto zeolite and limestone. Abstr. Pap. Am. Chem. Soc. 2008, 235, 1. [CrossRef]

28. Kuroki, V.; Bosco, G.E.; Fadini, P.S.; Mozeto, A.A.; Cestari, A.R.; Carvalho, W.A. Use of a La(III)-modified bentonite for effective phosphate removal from aqueous media. J. Hazard. Mater. 2014, 274, 124-131. [CrossRef] 
29. Yan, L.G.; Xu, Y.Y.; Yu, H.Q.; Xin, X.D.; Wei, Q.; Du, B. Adsorption of phosphate from aqueous solution by hydroxy-aluminum, hydroxy-iron and hydroxy-iron-aluminum pillared bentonites. J. Hazard. Mater. 2010, 179, 244-250. [CrossRef] [PubMed]

30. Gunawan, E.K.; Warmadewanthi, X.; Liu, J.C. Removal of phosphate and fluoride from optoelectronic wastewater by calcite. Int. J. Environ. Technol. Manag. 2010, 12, 3-4. [CrossRef]

31. Karageorgiou, K.; Paschalis, M.; Anastassakis, G.N. Removal of phosphate species from solution by adsorption onto calcite used as natural adsorbent. J. Hazard. Mater. 2007, 139, 447-452. [CrossRef]

32. Liu, Y.; Sheng, X.; Dong, Y.H.; Ma, Y.J. Removal of high-concentration phosphate by calcite: Effect of sulfate and pH. Desalination 2012, 289, 66-71. [CrossRef]

33. Karaca, S.; Gurses, A.; Ejder, M.; Acikyildiz, M. Kinetic modeling of liquid-phase adsorption of phosphate on dolomite. J. Colloid Interface Sci. 2004, 277, 257-263. [CrossRef]

34. Ayoub, G.M.; Kalinian, H. Removal of low-concentration phosphorus using a fluidized raw dolomite bed. Water Environ. Res. 2006, 78, 353-361. [CrossRef]

35. Karaca, S.; Gurses, A.; Ejder, M.; Acikyildiz, M. Adsorptive removal of phosphate from aqueous solutions using raw and calcinated dolomite. J. Hazard. Mater. 2006, 128, 273-279. [CrossRef] [PubMed]

36. Yin, H.B.; Yun, Y.; Zhang, Y.L.; Fan, C.X. Phosphate removal from wastewaters by a naturally occurring, calcium-rich sepiolite. J. Hazard. Mater. 2011, 198, 362-369. [CrossRef] [PubMed]

37. Haddad, K.; Jellali, S.; Jaouadi, S.; Benltifa, M.; Mlayah, A.; Hamzaoui, A.H. Raw and treated marble wastes reuse as low cost materials for phosphorus removal from aqueous solutions: Efficiencies and mechanisms. C. R. Chim. 2015, 18, 75-87. [CrossRef]

38. Jaouadi, S.; Wahab, M.A.; Anane, M.; Bousselmi, L.; Jellali, S. Powdered marble wastes reuse as a low-cost material for phosphorus removal from aqueous solutions under dynamic conditions. Desalin. Water Treat. 2014, 52, 1705-1715. [CrossRef]

39. Wu, J.; Tang, X.; Yang, G.; Sun, B.Y.; Yang, Q. Removing phosphorus from phosphorus-containing industrial wastewater using modified marble powder as chemical precipitant. In Proceedings of the 2010 4th International Conference on Bioinformatics and Biomedical Engineering, Chengdu, China, 18-20 June 2010.

40. Eljamal, O.; Okawauchi, J.; Hiramatsu, K.; Harada, M. Phosphorus sorption from aqueous solution using natural materials. Environ. Earth Sci. 2013, 68, 859-863. [CrossRef]

41. Brogowski, Z.; Renman, G. Characterization of opoka as a basis for its use in wastewater treatment. Pol. J. Environ. Stud. 2004, 13, 15-20. [CrossRef]

42. Bus, A.; Karczmarczyk, A. Properties of lime-siliceous rock opoka as reactive material to remove phosphorous from water and wastewater. Infrastrukt. Ekol. Teren. Wiej. 2014, 227-238. [CrossRef]

43. Cucarella, V.; Zaleski, T.; Mazurek, R. Phosphorus sorption capacity of different types of opoka. Ann. Wars. Univ. Life Sci.-SGGW Land Reclam. 2007, 1, 11-18. [CrossRef]

44. Johansson, L. Industrial by-products and natural substrata as phosphorus sorbents. Environ. Technol. 1999, 20, 309-316. [CrossRef]

45. Jóźwiakowski, K. Experiment of increasing effectiveness of phosphorus removal in a model of wastewater treatment plant. Inżynieria Rol. 2006, 5, 249-256.

46. Nilson, C. Phosphorus Removal in Reactive Filter Materials-Factors Affecting the Sorption Capacity TRITA LWR LIC 2066; Royal Institute of Technology: Stockholm, Sweden, 2012.

47. Johansson, L.; Hylander, L. Phosphorus removal from wastewater by filter media: Retention and estimated plant availability of sorbed phosphorus. J. Pol. Acad. Sci. 1998, 48, 397-409.

48. Vohla, C.; Koiv, M.; Bavor, H.J.; Chazarenc, F.; Mander, U. Filter materials for phosphorus removal from wastewater in treatment wetlands-A review. Ecol. Eng. 2011, 37, 70-89. [CrossRef]

49. Vymazal, J. Removal of Phosphorus in Constructed Wetlands with Horizontal Sub-Surface Flow in the Czech Republic. Water Air Soil Pollut. Focus 2002, 4. [CrossRef]

50. Karczmarczyk, A.; Renman, G. Phosphorus Accumulation Pattern in a Subsurface Constructed Wetland Treating Residential Wastewater. Water 2011, 3, 146-156. [CrossRef]

51. Arias, C.A.; Del Bubba, M.; Brix, H. Phosphorus removal by sands for use as media in subsurface flow constructed reed beds. Water Res. 2001, 35, 1159-1168. [CrossRef]

52. Veith, J.A.; Sposito, G. Use of langmuir equation in interpretation of adsorption phenomena. Soil Sci. Soc. Am. J. 1977, 41, 697-702. [CrossRef] 
53. Vohla, C.; Poldvere, E.; Noorvee, A.; Kuusemets, V.; Mander, U. Alternative filter media for phosphorous removal in a horizontal subsurface flow constructed wetland. J. Environ. Sci. Health Part A-Toxic/Hazard. Subst. Environ. Eng. 2005, 40, 1251-1264. [CrossRef]

54. Bellier, N.; Chazarenc, F.; Comeau, Y. Phosphorus removal from wastewater by mineral apatite. Water Res. 2006, 40, 2965-2971. [CrossRef]

55. Postila, H.; Karjalainen, S.M.; Klove, B. Can limestone, steel slag or man-made sorption materials be used to enhance phosphate-phosphorus retention in treatment wetland for peat extraction runoff with low phosphorous concentration? Ecol. Eng. 2017, 98, 403-409. [CrossRef]

56. Li, L.Y.; Zhang, H.; Wang, D.Q. Influencing Factors of Limestone Sorption and its Usage in Advanced Wastewater Treatment for Phosphorus Removal. In Proceedings of the 4th International Conference on Environmental Technology and Knowledge Transfer, Hefei, China, 24-25 May 2012.

57. Hedstrom, A. Wollastonite as reactive filter medium for sorption of wastewater ammonium and phosphorus. Environ. Technol. 2006, 27, 801-809. [CrossRef]

58. Gustafsson, J.P.; Renman, A.; Renman, G.; Poll, K. Phosphate removal by mineral-based sorbents used in filters for small-scale wastewater treatment. Water Res. 2008, 42, 189-197. [CrossRef] [PubMed]

59. Mann, R.A.; Bavor, H.J. Phosphorus removal in constructed wetlands using gravel and industrial-waste substrata. Water Sci. Technol. 1993, 27, 107-113. [CrossRef]

60. Zapater-Pereyra, M.; Malloci, E.; van Bruggen, M.A.; Lens, P.N.L. Use of marine and engineered materials for the removal of phosphorus from secondary effluent. Ecol. Eng. 2014, 73, 635-642. [CrossRef]

61. Abeynaike, A.; Wang, L.Y.; Jones, M.I.; Patterson, D.A. Pyrolysed powdered mussel shells for eutrophication control: Effect of particle size and powder concentration on the mechanism and extent of phosphate removal. Asia-Pac. J. Chem. Eng. 2011, 6, 231-243. [CrossRef]

62. Vianna, M.T.G.; Marques, M.; Bertolino, L.C. Sun coral powder as adsorbent: Evaluation of phosphorus removal in synthetic and real wastewater. Ecol. Eng. 2016, 97, 13-22. [CrossRef]

63. Sovik, A.K.; Klove, B. Phosphorus retention processes in shell sand filter systems treating municipal wastewater. Ecol. Eng. 2005, 25, 168-182. [CrossRef]

64. Adam, K.; Krogstad, T.; Vrale, L.; Sovik, A.K.; Jenssen, P.D. Phosphorus retention in the filter materials shellsand and Filtralite P (R)-Batch and column experiment with synthetic P solution and secondary wastewater. Ecol. Eng. 2007, 29, 200-208. [CrossRef]

65. Roseth, R. Shell sand: A new filter medium for constructed wetlands and wastewater treatment. J. Environ. Sci. Health Part A-Toxic/Hazard. Subst. Environ. Eng. 2000, 35, 1335. [CrossRef]

66. Xiong, J.B.; Qin, Y.; Islam, E.; Yue, M.; Wang, W.F. Phosphate removal from solution using powdered freshwater mussel shells. Desalination 2011, 276,317-321. [CrossRef]

67. Nesme, T.; Withers, P.J.A. Sustainable strategies towards a phosphorus circular economy. Nutr. Cycl. Agroecosyst. 2016, 104, 259-264. [CrossRef]

68. Xu, D.F.; Xu, J.M.; Wu, J.J.; Muhammad, A. Studies on the phosphorus sorption capacity of substrates used in constructed wetland systems. Chemosphere 2006, 63, 344-352. [CrossRef] [PubMed]

69. Dunets, C.S.; Zheng, Y.B.; Dixon, M. Use of phosphorus-sorbing materials to remove phosphate from greenhouse wastewater. Environ. Technol. 2015, 36, 1759-1770. [CrossRef] [PubMed]

70. Li, J.G.; Wu, B.R.; Zhou, T.; Chai, X.L. Preferential removal of phosphorus using modified steel slag and cement combination for its implications in engineering applications. Environ. Technol. Innov. 2018, 10, 264-274. [CrossRef]

71. Oguz, E. Removal of phosphate from aqueous solution with blast furnace slag. J. Hazard. Mater. 2004, 114, 131-137. [CrossRef] [PubMed]

72. Kuwahara, Y.; Yamashita, H. Phosphate Removal from Aqueous Solutions Using Calcium Silicate Hydrate Prepared from Blast Furnace Slag. ISIJ Int. 2017, 57, 1657-1664. [CrossRef]

73. Yasipourtehrani, S.; Strezov, V.; Evans, T. Investigation of Phosphate Removal Capability of Blast Furnace Slag in Wastewater Treatment. Sci. Rep. 2019, 9, 9. [CrossRef]

74. Qiu, B.B.; Duan, F. Synthesis of industrial solid wastes/biochar composites and their use for adsorption of phosphate: From surface properties to sorption mechanism. Colloid Surf. A-Physicochem. Eng. Asp. 2019, 571, 86-93. [CrossRef] 
75. Zhu, D.; Chen, Y.; Yang, H.; Wang, S.; Wang, X.; Zhang, S.; Chen, H. Synthesis and characterization of magnesium oxide nanoparticle-containing biochar composites for efficient phosphorus removal from aqueous solution. Chemosphere 2020, 247. [CrossRef]

76. Li, J.; Li, B.; Huang, H.M.; Lv, X.M.; Zhao, N.; Guo, G.J.; Zhang, D.D. Removal of phosphate from aqueous solution by dolomite-modified biochar derived from urban dewatered sewage sludge. Sci. Total Environ. 2019, 687, 460-469. [CrossRef]

77. Lama, N.H.; Ma, H.T.; Bashir, M.J.K.; Eppe, G.; Avti, P.; Nguyen, T.T. Removal of phosphate from wastewater using coal slag. Int. J. Environ. Anal. Chem. 2020, 1, 10-11. [CrossRef]

78. Oguz, E. Sorption of phosphate from solid/liquid interface by fly ash. Colloid Surf. A-Physicochem. Eng. Asp. 2005, 262, 113-117. [CrossRef]

79. Berg, U.; Donnert, D.; Weidler, P.G.; Kaschka, E.; Knoll, G.; Nueesch, R. Phosphorus removal and recovery from wastewater by tobermorite-seeded crystallisation of calcium phosphate. Water Sci. Technol. 2006, 53, 131-138. [CrossRef] [PubMed]

80. Renman, G.; Renman, A. Sustainable use of crushed autoclaved aerated concrete (CAAC) as a filter medium in wastewater purification. In Proceedings of the 8th International conference on sustainable management of waste and recycled materials in construction, Gothenburg, Sweden, 30 May-1 June 2012.

81. Jia, C.R.; Dai, Y.R.; Wu, C.Y.; Wu, Z.B.; Liang, W. Adsorption characteristics of used cement for phosphorus removal from wastewater. Fresenius Environ. Bull. 2013, 22, 2910-2915.

82. Malavipathirana, S.; Wimalasiri, S.; Priyanth, N.; Wickramasooriya, S.; Welagedara, A.; Renman, G. Value Addition to Waste Material Supported by Removal of Available Phosphate from Simulated Brackish Water-A LowCost Approach. J. Geosci. Environ. Prot. 2013, 1, 7-12. [CrossRef]

83. Buriánek, P.; Skalický, M.; Grünwald, A. Study of Phosphates Adsorption from Water by Recycled Concrete. J. Selcuk Univ. Nat. Appl. Sci. 2014, 17, 103-112.

84. Bus, A. The assessment of application autoclaved aerated concreate as a reactive materials for phosphorus removal from aquatic solutions. Infrastrukt. Ekol. Teren. Wiej. 2016, 3, 949-958. [CrossRef]

85. Boujelben, N.; Bouzid, J.; Elouear, Z.; Feki, A.; Jamoussi, F.; Montiel, A. Phosphorus removal from aqueous solution using iron coated natural and engineered sorbents. J. Hazard. Mater. 2008, 151, 103-110. [CrossRef]

86. Chen, J.; Yan, L.G.; Yu, H.Q.; Li, S.; Qin, L.L.; Liu, G.Q.; Li, Y.F.; Du, B. Efficient removal of phosphate by facile prepared magnetic diatomite and illite clay from aqueous solution. Chem. Eng. J. 2016, 287, 162-172. [CrossRef]

87. Ma, L.Y.; Zhu, J.X.; Xi, Y.F.; Zhu, R.L.; He, H.P.; Liang, X.L.; Ayoko, G.A. Adsorption of phenol, phosphate and $\mathrm{Cd}(\mathrm{II})$ by inorganic-organic montmorillonites: A comparative study of single and multiple solute. Colloid Surf. A-Physicochem. Eng. Asp. 2016, 497, 63-71. [CrossRef]

88. Nowack, B.; Stone, A.T. Competitive adsorption of phosphate and phosphonates onto goethite. Water Res. 2006, 40, 2201-2209. [CrossRef]

89. Maamoun, I.; Eljamal, O.; Khalil, A.M.E.; Sugihara, Y.; Matsunaga, N. Phosphate Removal Through Nano-Zero-Valent Iron Permeable Reactive Barrier; Column Experiment and Reactive Solute Transport Modeling. Transp. Porous Media 2018, 125, 395-412. [CrossRef]

90. Eljamal, O.; Thompson, I.P.; Maamoun, I.; Shubair, T.; Eljamal, K.; Lueangwattanapong, K.; Sugihara, Y. Investigating the design parameters for a permeable reactive barrier consisting of nanoscale zero-valent iron and bimetallic iron/copper for phosphate removal. J. Mol. Liq. 2020, 299, 11. [CrossRef]

91. Masłoń, A. Phosphorus removal from aqueous solutions using cement milk. Gaz Woda Tech. Sanit. 2016, 12, 457-461. [CrossRef]

92. Agyeia, M.; Strydomb, C.A.; Potgieterc, J.H. The removal of phosphate ions from aqueous solution by fly ash, slag, ordinary Portland cement and related blends. Cem. Concr. Res. 2002, 32. [CrossRef]

93. Masłoń, M.; Czarnota, J. Efficiency of Brick Dust and Powdered Ceramsite in the Phosphorus Removal from Wastewater. J. Ecol. Eng. 2020, 21. [CrossRef]

94. Penn, C.J.; Bryant, R.B.; Callahan, M.P.; McGrath, J.M. Use of Industrial By-products to Sorb and Retain Phosphorus. Commun. Soil Sci. Plant Anal. 2011, 42, 633-644. [CrossRef]

95. Li, Y.Z.; Liu, C.J.; Luan, Z.K.; Peng, X.J.; Zhu, C.L.; Chen, Z.Y.; Zhang, Z.G.; Fan, J.H.; Jia, Z.P. Phosphate removal from aqueous solutions using raw and activated red mud and fly ash. J. Hazard. Mater. 2006, 137, 374-383. [CrossRef] 
96. Sima, T.V.; Letshwenyo, M.W.; Lebogang, L. Efficiency of waste clinker ash and iron oxide tailings for phosphorus removal from tertiary wastewater: Batch studies. Environ. Technol. Innov. 2018, 11, 49-63. [CrossRef]

97. Szymczyk, P.; Filipkowska, U.; Jóźwiak, T. The use of aminated husks Arachis hypogaea for removal of orthophosphate from aqueous solutions. Inżynieria Ekol. 2017, 18, 167-174. [CrossRef]

98. Szymczyk, P.; Filipkowska, U.; Jóźwiak, T.; Kuczajowska-Zadrożna, M. Phosphate removal from aqueous solutions by chitin and chitosan in flakes. Prog. Chem. Appl. Chitin Deriv. 2016, 21, 192-202. [CrossRef]

99. Kaczmarczyk, A.; Woja, K.; Bliska, P.; Baryła, A.; Bus, A. The efficiency of filtration materials (Polonite ${ }^{\circledR}$ and Leca $\left.{ }^{\circledR}\right)$ supporting phosphorus removal in on site treatment systems with wastewater infiltration. Infrastruct. Ecol. Rural Areas 2017, 4, 1401-1413. [CrossRef]

100. Renman, A.; Renman, G. Long-term phosphate removal by the calcium-silicate material Polonite in wastewater filtration systems. Chemosphere 2010, 79, 659-664. [CrossRef] [PubMed]

101. Masłoń, A.; Tomaszek, J.A.; Opaliński, I.; Piech, A. Physicochemical properties of keramsite powder form in terms of the improvement of phosphorus removal from wastewater. Inż. Ap. Chem. 2015, 54, 106-108.

102. Czarnota, J.; Maslon, A. Biogranulation and Physical Properties of Aerobic Granules in Reactors at Low Organic Loading Rate and with Powdered Ceramsite Added. J. Ecol. Eng. 2019, 20, 202-210. [CrossRef]

103. Czarnota, J.; Maslon, A.; Zdeb, M. Powdered keramsite as unconventional method of AGS technology support in GSBR reactor with minimum-optimum OLR. In Proceedings of the 10th Conference on Interdisciplinary Problems in Environmental Protection and Engineering Eko-Dok, Polanica-Zdrój, Poland, 16-18 April 2018.

104. Maslon, A.; Tomaszek, J.A.; Zamorska, J.; Zdeb, M.; Piech, A.; Opalinski, I.; Jurczyk, L. The impact of powdered keramsite on activated sludge and wastewater treatment in a sequencing batch reactor. J. Environ. Manag. 2019, 237, 305-312. [CrossRef]

105. Zhu, T.; Jenssen, P.D.; Maehlum, T.; Krogstad, T. Phosphorus sorption and chemical characteristics of lightweight aggregates (LWA)—Potential filter media in treatment wetlands. Water Sci. Technol. 1997, 35, 103-108. [CrossRef]

106. Jenssen, P.D.; Krogstad, T. Design of Constructed Wetlands Using Phosphorus Sorbing Lightweight Aggregate (LWA); Wit Press: Southampton, UK, 2003; pp. 259-271.

107. Kasprzyk, M.; Gajewska, M. Phosphorus removal by application of natural and semi-natural materials for possible recovery according to assumptions of circular economy and closed circuit of P. Sci. Total Environ. 2019, 650, 249-256. [CrossRef]

108. Bus, A.; Kaczmarczyk, A.; Baryła, A. Choosing of reactive material for phosphorous removal from water and wastewater on the example of lightweight aggregate Pollytag ${ }^{\circledR}$. Inżynieria Ekol. 2014, 39, 33-41. [CrossRef]

109. Jourak, A.; Frishfelds, V.; Lundstrom, T.S.; Herrmann, I.; Hedstrom, A. Modeling of Phosphate Removal by Filtra $P$ in Fixed-bed Columns; International Association of Computer Science, Information Technology Press-Iacsit Press: Singapore, 2011; pp. 241-248.

110. Herrmann, I.; Jourak, A.; Lundstrom, T.S.; Hedstrom, A.; Viklander, M. Phosphorus binding to Filtra P in batch tests. Environ. Technol. 2012, 33, 1013-1019. [CrossRef]

111. Wendling, L.A.; Blomberg, P.; Sarlin, T.; Priha, O.; Arnold, M. Phosphorus sorption and recovery using mineral-based materials: Sorption mechanisms and potential phytoavailability. Appl. Geochem. 2013, 37, 157-169. [CrossRef]

(C) 2020 by the authors. Licensee MDPI, Basel, Switzerland. This article is an open access article distributed under the terms and conditions of the Creative Commons Attribution (CC BY) license (http://creativecommons.org/licenses/by/4.0/). 